Article

\title{
Where Are We Going? International Views on Purposes, Practices and Barriers in School-Based Outdoor Learning
}

\author{
Sue Waite $\mathbb{D}$ \\ Plymouth Institute of Education, University of Plymouth, Plymouth PL4 8AA, UK; sjwaite@plymouth.ac.uk \\ Received: 27 September 2020; Accepted: 27 October 2020; Published: 30 October 2020 \\ check for
updates
}

\begin{abstract}
Popular demand for school-based outdoor learning is growing throughout the world, but there is relatively little use of international comparisons to inform the development and support of this growth. Motivations for providing outdoor learning may vary within and across countries/areas. Through understanding how different purposes are being approached internationally, we can learn how outdoor learning might best be supported to achieve particular outcomes. Eighty expert commentators on outdoor learning from 19 countries/areas responded to a short online survey about motivations for and practices in school-based outdoor learning, based on their experience working in this field. The survey was designed using a conceptual framework of student outcomes from outdoor learning, derived from policy analysis and five major reviews of the field. The three most frequently reported forms of outdoor learning practiced in schools were field studies, early years outdoor activities, and outdoor and adventure education. Among identified purposes for outdoor learning provision within schooling, supporting environmental awareness and action and pupil health and well-being were the most common. Some alignment of forms of outdoor learning and specific outcomes are discussed and implications for future policy, practice, and research considered.
\end{abstract}

Keywords: policy; purposes; practice; barriers; outdoor learning; outdoor and adventure education; international perspectives; comparative

\section{Introduction}

Popular demand for outdoor learning is growing in the UK as elsewhere throughout the world, but there is relatively little use of international comparisons to inform the development and support of this growth [1]. Outdoor learning represents a very broad range of activity, and its interpretation in terms of meaning and practice is not consistent across cultures [2]. Within countries/areas, there is not necessarily common ground on how terms are used. Across nations, there is yet more scope for diverse interpretations. For the purposes of this research, we defined school-based outdoor learning as play, teaching, and learning that take place in natural environments for children in formal education and care settings.

Motivations for providing outdoor learning may also vary within and across countries/areas. We can learn much about how best to support outdoor learning in schools by understanding how different purposes are approached internationally $[3,4]$. Nevertheless, caution is needed as simply "borrowing" policies and practice can result in inappropriate translations from one context to another without attention to the particularities of cultural traditions and constraints that may impinge on successful implementation elsewhere [4,5]. Unfortunately, such detail is rarely provided within articles [2]. However, a lack of precise definition of terms perhaps also reflects that enacted processes and how they are received may differ from intentions and principles [6], introducing margins of error between theory, practice, and learner experience. 
Between 2012 and 2015, the UK Economic and Social Research Council funded an international partnership network that enabled researchers in England, Australia, Denmark, and Singapore to collaborate in comparing the development of outdoor learning across these countries/areas, and in 2016, a report [7] drew on this partnership, international research reviews, and an analysis of policy drivers to explore the extent to which outdoor learning supported key policy areas both within the UK and more broadly. From their analysis, Malone and Waite [7] found five student outcomes that aligned with contemporary policy priorities, related to developing "a healthy and happy body and mind; a sociable confident person; a self-directed and creative learner; an effective contributor; an active global citizen" (p. 5). At an international level, these strands are supported by the United Nations Convention for the Rights of the Child (UNCRC) [8]. Article 29 states the purpose of education is

1. The development of the child's personality, talents and mental and physical abilities to their fullest potential;

2. The development of respect for human rights and fundamental freedoms, and for the principles enshrined in the Charter of the United Nations;

3. The development of respect for the child's parents, his or her own cultural identity, language and values, for the national values of the country/area in which the child is living, the country/area from which he or she may originate, and for civilizations different from his or her own;

4. The preparation of the child for responsible life in a free society, in the spirit of understanding, peace, tolerance, equality of sexes, and friendship among all peoples, ethnic, national and religious groups and persons of indigenous origin;

5. The development of respect for the natural environment.

In the UK, these global policy aspirations have been evident in the recognition of health inequalities [9] that have driven several preventative public health strategies. The All Party Parliamentary Group on Social Mobility has reported links between personal and social skills that can be developed through outdoor learning and overcoming adversity throughout life [10], more creative and collaborative team workers have been called for future employment scenarios [11], and the interdependence of human and environmental well-being has been recognized in the 25-year plan for improving the environment [12]. In Scotland, educational policy supports these aims through the Curriculum for Excellence [13]. In some countries/areas, such as Canada, the US, and Australia, policy adoption of outdoor learning to support these drivers tends to be at state level, although there is Australia-wide policy for Education for Sustainable Development [14]. Sustainability is also the mainstay of policy support in Japan [15], while in Norway, Denmark, and Sweden (albeit the latter only at preschool level), it is linked to curriculum educational objectives.

Different forms of outdoor learning appeared to be better suited for specific outcomes, according to Malone and Waite's synthesis of evidence, and they recommended that more research and sector attention was needed to offer more nuanced provision across these desired student outcomes. In another collaboration as part of this international partnership, Waite, Bølling and Bentsen [1] proposed a framework for comparing different forms of outdoor learning using Bereday's comparative process, and illustrating principles through the case of comparing the Danish udeskole movement and British Forest School. The framework principles included "purpose, aims, content, pedagogy, outcome, and barriers" (p. 871). Adopting a systematic process of comparison enables greater nuance in choosing distinct forms of outdoor and adventure education for specific desired purposes.

Literature that undertakes international comparisons of outdoor learning forms or policies or even adequately situates research in its material, cultural, and social context is still relatively rare $[4,7,16-19]$, but the body of research into outdoor learning across nations has exploded over recent years [20]. Networks such as the Play, Learning and Teaching Outdoors network (PLaTO-net), International School Grounds Alliance (ISGA) and the Joint Information Systems Committee (JISC) discussion forum OUTRES, together with international projects such as those funded within the European 
Union ERASMUS+ program, have provided valuable forums for international discussion; nonetheless, consensus over terms and definitions is patchy [2].

Several reviews conducted in the last 20 years have, however, helped to summarize the current field of knowledge [21-25]. Taken together, they identify significant evidence that outdoor learning, broadly defined, improves children's quality of life and point to the fact that outdoor learning can meet many desired policy outcomes for young people's well-being now and in the future. Rickinson and colleagues [21] synthesized evidence between 1993 and 2003 on outdoor learning at primary, secondary, and higher education levels and noted attention to the learning process in research on both outdoor adventure education and fieldwork, and a growing interest in spatial influences, demonstrated in emergent school grounds research. Four years later, UK governmental policy interest in learning outside the classroom stimulated a commissioned review, Every Experience Matters [22], which drew on international research on learning outside the classroom and its impacts on children aged 0-18. The author, Karen Malone, found evidence of positive effects on academic attainment, physical fitness and motor skills, confidence, self-esteem and social skills, leadership potential, and environmental responsibility through time spent in learning outside the classroom. Gill's review in 2011 [23] focused particularly on 61 studies of outdoor play and learning in natural environments and reported significant support in them for time spent in nature as a child being associated with greater knowledge about the environment and enduring pro-environmental attitudes, improved mental health and emotional regulation, and greater physical activity levels, motor skills, and fitness. A systematic review commissioned by the UK Blagrave Trust and Institute of Outdoor Learning [24], synthesizing 57 UK-based studies and 15 international reviews, found that adventure and residential activity with young people aged 11 and over was the most studied form of outdoor learning. Studies were, however, predominately qualitative and rarely addressed predicted effects or longer term curricular or employability outcomes, seemingly gaining little traction with policymakers. Dillon and Dickie [25] specifically targeted demonstration of the benefits of learning in natural environments through schools. Their review was underpinned by an economic analysis of the cost-benefits of including outdoor learning as part of schools' offers. They concluded that ample evidence exists that health, community cohesion, and attainment costs to UK society from the adverse effects of inadequate exposure to natural environments could be reduced by about GBP $10-20$ million by embedding this provision within schools.

Over a similar period, there has been an acceleration in the decline in many Western countries/areas of children's opportunities to be outdoors in formal or informal learning settings through an academic emphasis on attainment [26], increased screen time and more supervised out-of-home activity [27], and various pressures on family leisure time [28]. Concern about these reductions in children's exposure to natural environments [29] is gathering momentum internationally because it has been demonstrated that time spent outdoors impacts positively on physical and mental health and well-being [30] and "character capabilities" such as engagement with and self-regulation of learning, resilience, creativity, and empathy for others and the natural world [22]. These so-called "soft skills" underpin success in learning and making valuable contributions to society [15,31].

To gain further insight into what the international picture of policy and practice might be, a survey funded by the UK Wildlife Trusts (the Wildlife Trusts comprise 46 individual Wildlife Trusts in the UK, charitable bodies formed by regional groups of people getting together to make a positive difference to wildlife and future generations, federated under the Royal Society of Wildlife Trusts, a registered charity founded in 1912) was sent in September/October 2017 to expert commentators on outdoor learning through personal contacts and networks. The purpose of this article is to consider some current trends across the different parts of the world that participated in the research in order to offer insights into how outdoor learning provision is being shaped and practiced to contribute to discussion around the theme of this special issue. The hope is that this window into current commonalities and differences will help policy makers, practitioners, and researchers identify and consider where more 
effort in the future might be directed to maximize the positive impacts of time spent learning outside by children and young people in economically challenging times post COVID-19.

\section{Materials and Methods}

The aim of the study was to survey international expert commentators on outdoor learning from about 10-15 countries/areas to provide contextualization for the Wildlife Trusts' work with schools and to support a clearer theory of change for their educational strategy development. The research questions pertinent to this article are: What are the purposes and policy drivers for school-based outdoor learning across different nations? What forms of outdoor learning are used in various countries/areas? What barriers to outdoor learning are experienced in different countries/areas?

Because of a limited budget and time frame for the research, it was decided to utilize an online survey method and seek respondents through a purposive sample of personal contacts and networks in the field. A pragmatic methodology [32] was considered appropriate to acknowledge "current truth, meaning and knowledge as tentative and as changing over time" (p. 28), accepting that the data gathered using this approach would be "provisional truths" that would be subject to further exploration. The networks approached included the International School Grounds Alliance, the Institute of Outdoor Learning research hub network; JISC discussion group OUTRES, the Economic and Social Research Council (ESRC) international partnership network on outdoor learning, and ERASMUS + collaborators, plus additional international contacts from conferences, projects, and previous correspondence. Those sent the link to the questionnaire by email were asked to share it with appropriate other contacts and networks, using a snowballing recruitment strategy to obtain the widest sample achievable within a tightly defined period (three weeks). It is not therefore possible to report a response rate as it is not known how many people received the invitation to participate. The number of respondents was 80 from 19 countries/areas as shown in Table 1. Not all respondents answered all questions.

Table 1. Number of respondents by country/area.

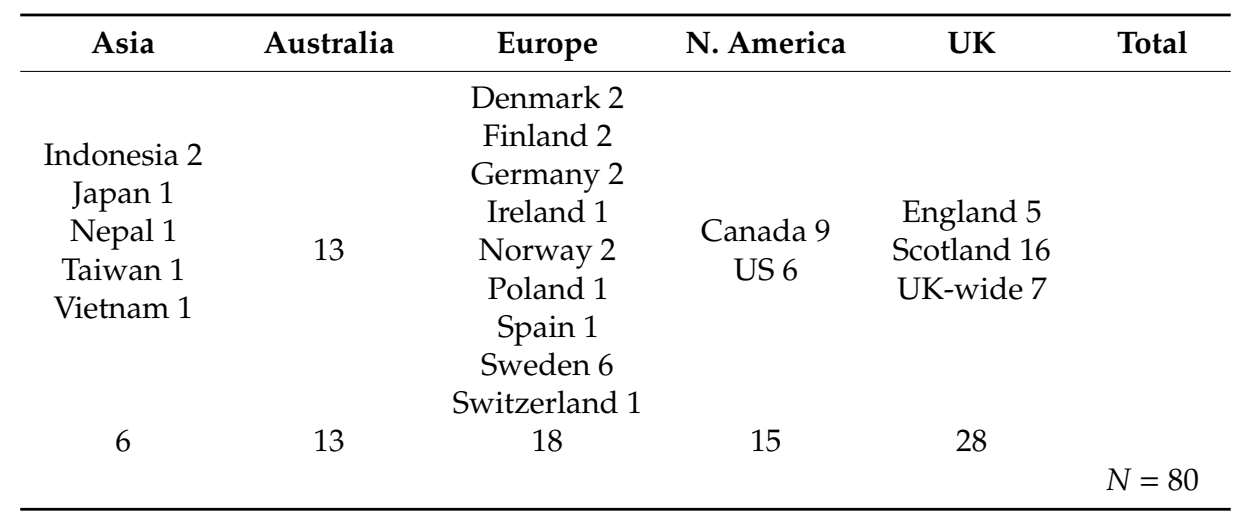

The survey was deliberately directed towards "experts" in the outdoor learning sector, both practitioners and researchers, using purposive sampling, as the original intention of the research was to gather impressions about the current state of play regarding outdoor learning in diverse countries/areas to explore commonalities. The definition of expert used was someone with a high level of knowledge or skill in outdoor learning. The identification of experts to invite was determined through personal knowledge of their work or their membership in academic and practitioner groups, which was considered indicative of a level of commitment, qualifications, and/or experience across organizational, academic, and practical dimensions of the field. To moderate possible dilution of expertise through the snowballing method of recruitment, participants were asked to rate their capability of completing the survey from their knowledge and experience. A total of $92 \%$ of respondents felt well or fairly well qualified to answer the questions posed. Only four respondents reported that they felt "not well qualified" to complete the survey. Not all questions were answered by all respondents; they may have 
been left blank if they were beyond respondents' expertise. Some participants pointed out that policies and practice varied within their countries, and that their comments related to their regional situation or impressions of the wider picture in their nation. For these reasons and because some countries/areas were represented by only one expert opinion, the reports should be considered only indicative of areas of commonality or difference.

The development of the survey questions was based on previous research. For example, the student outcomes generated through an analysis of literature and policy drivers [7] created a frame of reference for purposes, although participants were also invited to share other ideas throughout the questionnaire. Other questions were derived from earlier research looking at barriers to the provision of curriculum-based outdoor learning [33,34] and declines in outdoor learning during schooling [26]. Within the pragmatic approach as bricoleur researcher, it is considered acceptable to use "whatever resources and repertoire one has to perform whatever task one faces" [35]. The survey design was kept simple in recognition of the short time frame available for completion and analysis. It was decided to use a three-point Likert scale as, with a relatively small number of anticipated respondents, responses spread over a wider scale might have needed to be reaggregated for meaningful reporting. A draft of the survey was sense checked with an outdoor learning policy maker, practitioner, and researcher who were not completing the survey. Examples and additional comments were invited to enable different perspectives to surface through the survey. The questionnaire can be viewed in Appendix A in full. Because of the small number of respondents and the intention to provide impressions based on expert views, descriptive analysis was used for both quantitative and qualitative data, and interpretive analysis about possible implications was based on this and extant literature.

To comply with standard ethical practices, all those invited were free to participate or not without any penalty. Their identity was not revealed in the report unless with specific permission.

\section{Results}

In compiling the report for the funding body [36], general trends were reported to provide a reflective 'mirror' for the organization's policies and practice, but for the purposes of this article, commonalities and differences between the countries/areas represented in the survey are included. The framework for reporting broadly follows that proposed by Waite, Bølling and Bentsen [1] examining "purpose, aims, content, pedagogy, outcome, and barriers" (p. 871) where data are available. In this article, purpose, aims and outcomes are discussed together, content is included through comparisons of forms of outdoor learning present in countries/areas, and perceived barriers that obstruct provision are detailed.

\subsection{Purposes, Aims and Outcomes of Outdoor Learning}

When asked what the main drivers for outdoor learning were in their country/area, between 61 and 64 respondents from 19 countries/areas answered using a three-point Likert scale to indicate whether they agreed with the five desired 21st century student outcomes identified by Malone and Author [7]. Participants also offered further comments. For example, effective delivery of the curriculum was mentioned as a driver in Scotland, while a Danish respondent noted,

Giving meaningfulness to the topics being taught by connections between surroundings and the topic.

In Denmark, education policy advocates the relevance of learning in contexts other than the classroom, and although there is a grassroots movement for education outside the classroom, udeskole, this is further endorsed and promoted through top-down government investment and research encouraging this [37].

In the US, the principal drivers were identified as health in terms of raising levels of physical activity and awareness of healthy eating, as well as science education.

Physical Education and Physical Activity are the biggest drivers for outdoor learning, followed by nutrition and science education. 
The respondents from Finland and Norway mentioned knowledge and skills in biology and ecology for "nature-friendly behavior."

In Table 2, cells are shaded to show the pattern of response by country across the five policy drivers so that darker grey means respondents reported it as a main driver, light grey means they thought it was a main driver to a degree, and white means it was not considered a main driver. Where there was more than one respondent in the country, the response included was the one chosen by the most people. The number of respondents to the questions about different policy drivers varied as shown.

Table 2. Comparison of main drivers of outdoor learning in participating countries/areas.

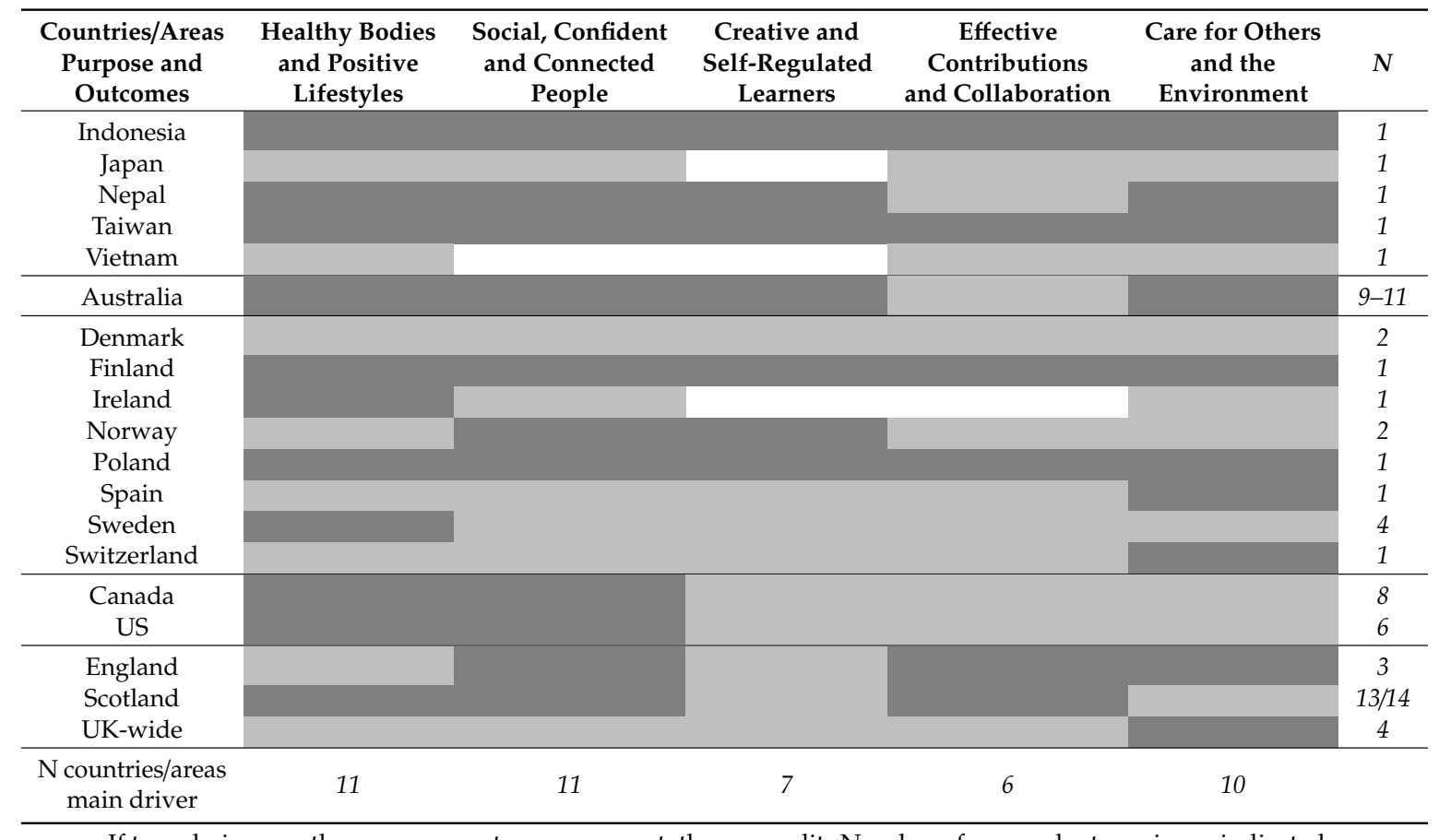

If two choices are the same percentage agreement, they are split. Number of respondents varies as indicated.

Table 2 shows that the dominant drivers across countries/areas according to survey respondents were children's health and well-being, developing social, confident, and connected people, and care for others and the environment. Surprisingly, the driver that gained least traction across participating countries' respondents was supporting collaboration, yet this is a commonly attributed outcome from outdoor learning [24]. In the following sections, this overview is further broken down to explore each driver.

\subsubsection{Encouraging Healthy Bodies and Positive Lifestyles}

In Table 3 the respondents from the majority of countries/areas seemed to recognize that children's health and well-being were powerful driving forces for providing access to outdoor learning for all schoolchildren. However, it was reported as only influential to a degree by respondents in Japan, Vietnam, Spain, Switzerland, and England. Article 24 of the United Convention for the Rights of the Child [8] enshrines physical and mental fulfillment as fundamental to the quality of children's lives globally. One respondent from Scotland commented that,

At the moment in Scotland it is about meeting the needs of all children and young people, the recognition of wider achievement and the need to find effective ways of raising attainment in literacy and maths. Health and Wellbeing have a huge part too-but certainly the political expectations on schools and early years and childcare settings is high re. attainment at the moment and closing the gap. 
Table 3. Main driver of outdoor learning: Healthy bodies and positive lifestyles.

\begin{tabular}{|c|c|c|c|c|}
\hline Countries/Areas & Yes & To a Degree & No & Nof Responses \\
\hline Indonesia & 1 & & & 1 \\
\hline Japan & & 1 & & 1 \\
\hline Nepal & 1 & & & 1 \\
\hline Taiwan & 1 & & & 1 \\
\hline Vietnam & & 1 & & 1 \\
\hline Australia & 10 & 1 & & 11 \\
\hline Denmark & 1 & 1 & & 2 \\
\hline Finland & 1 & & & 1 \\
\hline Ireland & 1 & & & 1 \\
\hline Norway & 1 & 1 & & 2 \\
\hline Poland & 1 & & & 1 \\
\hline Spain & & 1 & & 1 \\
\hline Sweden & 4 & & & 4 \\
\hline Switzerland & & 1 & & 1 \\
\hline Canada & 6 & 2 & & 8 \\
\hline US & 4 & 2 & & 6 \\
\hline England & & 2 & 1 & 3 \\
\hline Scotland & 11 & 3 & & 14 \\
\hline \multirow[t]{2}{*}{ UK-wide } & 2 & 2 & & 4 \\
\hline & & & & $N=64$ in 19 countries/areas \\
\hline
\end{tabular}

\subsubsection{Developing Social, Confident and Connected People}

In comparing responses in Table 4, it seemed for the UK [38] and North America particularly, that outdoor education as a root of school-based outdoor learning may have underpinned the recognition that "soft skills" such as positive social interactions and self-confidence were important outcomes from outdoor activity, traditionally acquired through challenging residentials in outdoor activity centers. In Canada, it was reported as the most influential driver. The picture was more mixed within European pedagogical traditions [1], where these qualities were commonly addressed throughout the educational experience inside and outside the classroom. In Vietnam, Japan, Ireland, Spain, and Switzerland, its importance was considered moderate. In Spain, a respondent noted that the emphasis depended on children's ages:

0-6 is more concerned about gaining confidence, autonomy, self-regulation, healthy environments. $6-16$ is more related to care for the environment, enrich curriculum contents, direct experience but related to official curriculum contents.

Table 4. Main driver of outdoor learning: Developing social, confident, and connected people.

\begin{tabular}{ccccc}
\hline Countries/Areas & Yes & To a Degree & No & Nof Responses \\
\hline Indonesia & 1 & & & 1 \\
Japan & & 1 & 1 \\
Nepal & 1 & & 1 \\
Taiwan & 1 & & 1 \\
Vietnam & & & 11 \\
\hline Australia & 9 & 2 & 2 & 1 \\
Denmark & 1 & 1 & 1 \\
Finland & 1 & & 1 \\
Ireland & & 1 & 1 \\
Norway & 2 & & \\
Poland & 1 & & \\
Spain & & 1 & & \\
\hline
\end{tabular}


Table 4. Cont.

\begin{tabular}{ccccc}
\hline Countries/Areas & Yes & To a Degree & No & N of Responses \\
\hline Sweden & 2 & 2 & & 4 \\
Switzerland & & 1 & & 8 \\
\hline Canada & 6 & 2 & 6 \\
US & 2 & 4 & & 3 \\
\hline England & 2 & & & 4 \\
Scotland & 8 & 6 & & $N=64$ in 19 countries/areas \\
UK-wide & 1 & 3 &
\end{tabular}

\subsubsection{Stimulating Creative and Self-Regulated Learners}

There appeared to be more ambivalence among respondents within and across countries/areas about the extent to which stimulating creative and self-regulated learners was a main driver of outdoor learning in their context. As we see in Table 5, four respondents reported this was not a motivation in their country/area. It may be that absence of endorsement within educational policy and strong performativity agenda in Japan, North America, and Ireland moderated the extent to which outdoor learning was valued or used specifically for educational attainment outcomes [26].

Table 5. Main driver of outdoor learning: Stimulating creative and self-regulated learners.

\begin{tabular}{|c|c|c|c|c|}
\hline Countries/Areas & Yes & To a Degree & No & $N$ of responses \\
\hline Indonesia & 1 & & & 1 \\
\hline Japan & & & 1 & 1 \\
\hline Nepal & 1 & & & 1 \\
\hline Taiwan & 1 & & & 1 \\
\hline Vietnam & & 1 & & 1 \\
\hline Australia & 5 & 5 & & 10 \\
\hline Denmark & 1 & 1 & & 2 \\
\hline Finland & 1 & & & 1 \\
\hline Ireland & & & 1 & 1 \\
\hline Norway & 1 & & & 2 \\
\hline Poland & 1 & & & 1 \\
\hline Spain & & 1 & & 1 \\
\hline Sweden & & 4 & & 4 \\
\hline Switzerland & & 1 & & 1 \\
\hline Canada & 2 & 4 & 2 & 8 \\
\hline US & 1 & 4 & 1 & 6 \\
\hline England & 1 & 2 & & 3 \\
\hline Scotland & 6 & 7 & & 13 \\
\hline \multirow[t]{2}{*}{ UK-wide } & 2 & 2 & & 4 \\
\hline & & & & $N=62$ in 19 countries/areas \\
\hline
\end{tabular}

\subsubsection{Supporting Effective Contributions and Collaboration}

Table 6 shows that well established links between outdoor learning and improved social skills and teamwork [39] appeared only moderately instrumental as principal motivations for outdoor learning. This is perhaps surprising given that collaboration and working with others are highly valued employability skills [11] and are also fundamental to children's happiness and success in future life [10]. Strongest support was indicated by respondents in Indonesia, Taiwan, Finland, Poland, and England. Some respondents (from Canada, the US, and the UK) did not think it acted as a main driver. 
Table 6. Main driver of outdoor learning: Supporting effective contributions and collaboration.

\begin{tabular}{|c|c|c|c|c|}
\hline Countries/Areas & Yes & To a Degree & No & N of Responses \\
\hline Indonesia & 1 & & & 1 \\
\hline Japan & & 1 & & 1 \\
\hline Nepal & & 1 & & 1 \\
\hline Taiwan & 1 & & & 1 \\
\hline Vietnam & & 1 & & 1 \\
\hline Australia & 4 & 5 & & 9 \\
\hline Denmark & 1 & 1 & & 2 \\
\hline Finland & 1 & & & 1 \\
\hline Ireland & & & 1 & 1 \\
\hline Norway & 1 & 1 & & 2 \\
\hline Poland & 1 & & & 1 \\
\hline Spain & & 1 & & 1 \\
\hline Sweden & & 4 & & 4 \\
\hline Switzerland & & 1 & & 1 \\
\hline Canada & 2 & 3 & 3 & 8 \\
\hline US & 2 & 3 & 1 & 6 \\
\hline England & 2 & & 1 & 3 \\
\hline Scotland & 7 & 6 & & 13 \\
\hline UK-wide & 1 & 2 & 1 & 4 \\
\hline
\end{tabular}

\subsubsection{Underpinning Care and Action for Others and the Environment}

Only one respondent from North America reported that environmental issues were not a main driver; overwhelmingly, this purpose was strongly supported by most countries/areas represented in the research as shown in Table 7. There was notable consensus among the participants from Australia that it was a major motivation there. Although it was recognized as a purpose by respondents in both England and Scotland, it seems that it may have been more significantly motivating in England. The Scottish Curriculum for Excellence [14] does not prescribe what is taught in the way the content-driven English National Curriculum [40] does, and outdoor learning and education for sustainability are promoted in Scottish governmental policy [41]. It may be that outdoor learning in England tends to be promoted at grassroots level by teachers who personally value the natural environment, and their values act as a stimulus to making time for it in busy timetables [42].

Table 7. Main driver of outdoor learning: Underpinning care and action for others and the environment.

\begin{tabular}{ccccc}
\hline Countries/Areas & Yes & To a Degree & No & Nof Responses \\
\hline Indonesia & 1 & & 1 \\
Japan & & 1 & 1 \\
Nepal & 1 & & 1 \\
Taiwan & 1 & & 1 \\
Vietnam & & 1 & 1 \\
\hline Australia & 9 & 1 & 10 \\
\hline Denmark & 1 & 1 & 2 \\
Finland & 1 & & 1 \\
Ireland & & 1 & 2 \\
Norway & 1 & 1 & 1 \\
Poland & 1 & & 1 \\
Spain & & 1 & 1 \\
Sweden & 2 & 2 & 8 \\
Switzerland & 1 & & 6 \\
\hline Canada & 3 & 4 & 1 & 3 \\
US & 2 & 4 & & \\
England & 2 & 1 & & \\
\hline
\end{tabular}


Table 7. Cont.

\begin{tabular}{ccccc}
\hline Countries/Areas & Yes & To a Degree & No & N of Responses \\
\hline Scotland & 5 & 9 & 14 \\
UK-wide & 3 & 1 & 4 \\
\hline & & & $N=63$ in 19 countries/areas \\
\hline
\end{tabular}

\subsubsection{Policies and Values as Drivers}

Of the responses received to the survey, Scotland, Indonesia, Japan, and parts of Australia indicated the strongest support through government policy for outdoor learning. As one respondent from Scotland reported:

Teacher standards require use of outdoor learning and understanding of Learning for Sustainability within a values-based Professional Accreditation system. Curriculum for Excellence states, 'outdoors is often a better place than indoors to learn' and Outdoor Learning is a regular and progressive experience for all learners.... We also have a requirement that all leadership support outdoor learning under new leadership qualifications, local authorities support school grounds to allow 'contact with nature on a daily basis' and 'green space suitable for teaching and learning' and Scotland's play policy and strategy also highlights our children's entitlement to 'free play opportunities, with daily contact with nature.

Outdoor learning is also included within the statewide curriculum in Victoria in Australia, where a government interdepartmental working group is also tasked with exploring ways to embed outdoor learning in recognition of its potential to fulfill several wider policy aspirations. There are moves to include it within the nationwide Australian Curriculum. In parts of Australia, as in several other countries/areas, education for sustainability appears to be a very strong motivation for outdoor learning recognized by individual teachers and in policy alike.

For us, it is based on relationships with self, others and nature. With a foundational basis of sustainability.

In Japan, the Ministry of Education, Culture, Sports, Science and Technology is working with UNESCO to develop programs for Education for Sustainable Development through schools and communities, with some schools acting as hubs of good practice. This grounded method of expansion has also been used in the Natural Connections Demonstration project, commissioned by the Department for the Environment Food and Rural Affairs in England (DEFRA), Historic England and Natural England [34], where 125 schools were supported in embedding sustainable curriculum-based outdoor learning through networks of schools with varying degrees of experience in outdoor learning.

In Norway it is part of the national curriculum, and it features in the early years, physical education, and biology curricula in Sweden. In England, educational policy support is mostly within early years provision, but recently DEFRA and the Department for Education have commissioned further trials to develop "nature-friendly schools" [43]. Among other drivers cited, Education for Sustainable Development, connection to and knowledge about nature, risk awareness, and diverse and experiential learning environments for curriculum delivery were also mentioned. As Waite found in a survey in the southwest of England [42], respondents to the survey noted that motivations were often shaped at a local level according to teachers' or delivery organizations' interests.

\subsection{Content of Outdoor Learning}

Regarding the content of the outdoor learning conducted in various countries/areas, a range of forms of outdoor learning were suggested in the questionnaire and respondents indicated whether they were often, sometimes, or not used in their country/area. The types were simply named in the questionnaire and not further defined so as not to impose one particular English conceptualization of 
the term. A given definition might not necessarily have general acceptance within England, and given the international nature of the survey, it was also considered important to avoid representing only one national perspective. Of course, it follows that names might conjure rather different ideas for participating countries/areas, but leaving the terms open maintained flexibility about interpretations and the comments boxes allowed respondents to explain further if they wished to do so and to add other forms. Ideas added included camps (Canada), visits to cultural places (Denmark), nature kindergarten, Bikeability and John Muir Award (Scotland), river, beach, mount (Indonesia).

\subsubsection{Forest School and Bushcraft}

Forest School, which is a growing phenomenon globally [44], was reported as most prevalent in England, Scotland, and Canada and was not observed at all in Norway or Nepal. It was reported that it sometimes or often occurred in $84 \%$ of the 19 countries/areas, according to responses received. It is described by the Forest School Association (FSA) [45] as:

A child-centred inspirational learning process, that offers opportunities for holistic growth through regular sessions. It is a long-term program that supports play, exploration and supported risk taking. It develops confidence and self-esteem through learner inspired, hands-on experiences in a natural setting.

The FSA proposes six principles that are supposed to characterize this form of outdoor learning, but in practice these are not always adhered to and a recent special issue on Forest School of the Journal of Outdoor and Environmental Education problematized the concept and its translation into different contexts [46].

Interestingly, bushcraft as a form of outdoor learning was not recognized by respondents from Finland, Poland, Spain, or Nepal. Given its emphasis on the acquisition of practical skills, there may be some overlap with the concept of Forest Schools. For example, Australian early years providers that use nature-based play may describe themselves as bush kindergarten. Although rarely reported as often used (6\%), bushcraft was reported as sometimes used in $65 \%$ of the countries/areas.

\subsubsection{Field Studies}

Field studies were widely reported across the responding countries/areas ( $98 \%$ often or sometimes). This is perhaps unsurprising as field studies is an established part of several academic subjects, such as geography and science. Field studies carry out investigative work in the world beyond the classroom and therefore might be seen as having some commonality with conceptualizations of Danish udeskole or learning outside the classroom in the UK.

\subsubsection{Embedded On-Site Curricular Outdoor Learning}

This form of outdoor learning was reported as fairly prevalent, as shown in Table 8 .

Table 8. Prevalence of embedded on-site curricular outdoor learning.

\begin{tabular}{ccccc}
\hline Countries/Areas & Yes (Often) & Yes (Sometimes) & No & N of Responses \\
\hline Indonesia & & 1 & & 1 \\
Japan & & 1 & 1 \\
Nepal & & 1 & 1 \\
Taiwan & & 1 & 1 \\
Vietnam & 3 & 7 & & 1 \\
\hline Australia & 2 & & 10 \\
\hline Denmark & & 1 & 2 \\
Finland & & 1 & 1 \\
Ireland & 2 & 1 & 2 \\
Norway & & & 1 \\
Poland & & &
\end{tabular}


Table 8. Cont.

\begin{tabular}{|c|c|c|c|c|}
\hline Countries/Areas & Yes (Often) & Yes (Sometimes) & No & Nof Responses \\
\hline Spain & 1 & & & 1 \\
\hline Sweden & 1 & 3 & & 4 \\
\hline Switzerland & & 1 & & 1 \\
\hline Canada & 2 & 5 & & 7 \\
\hline US & 4 & 2 & & 6 \\
\hline England & 2 & 1 & & 3 \\
\hline Scotland & 5 & 7 & & 12 \\
\hline \multirow[t]{2}{*}{ UK-wide } & 2 & 2 & & 4 \\
\hline & & & & 60 in 19 countries \\
\hline
\end{tabular}

The most frequent use of this form was reported by respondents from Denmark, the US, and England. Alignment with the curriculum in countries/areas with a strong performance agenda for schools is understandable as teachers must meet standards and therefore may need to cover curriculum objectives more directly [42]. In Denmark, the confluence of top-down policy and bottom-up teacher-led growth likely contributed to its establishment as mainstream practice [47]. The respondent from Nepal noted that this form was not seen at all there.

\subsubsection{Natural Environment Play and Early Years Outdoor Activities}

These forms were reported as common across almost all nations with only the respondent from Nepal noting them absent. Norway, Switzerland, Indonesia, Japan, and Scotland were the countries/areas where natural environment play was most reported as often occurring. Participants from Denmark, Norway, Spain, Sweden, Indonesia, and Japan reported early years outdoor activities as often occurring.

\subsubsection{Outdoor and Adventure Education}

The usual process for this form of outdoor learning is making occasional trips remote from the normal place of learning to residential or day centers specializing in outdoor activities that offer a challenge such as climbing, kayaking, sailing. Frequently, special qualifications are required to lead such activities for health and safety reasons, and schoolteachers may not hold these additional qualifications, so it is common that they are provided by external organizations. This may explain the tendency for most countries/areas to report that outdoor and adventure education took place sometimes rather than often (Table 9). In Norway, the concept of friluftsliv, whereby outdoor living is highly valued and practiced within society, may account for its reported prevalence in this country/area [48]. Nevertheless, it seems that many children across the participating nations experienced the opportunity to engage in this sort of outdoor learning at least occasionally.

Table 9. Prevalence of outdoor and adventure education.

\begin{tabular}{ccccc}
\hline Countries/Areas & Yes (Often) & Yes (Sometimes) & No & Nof Responses \\
\hline Indonesia & 1 & & & 1 \\
Japan & & 1 & 1 & 1 \\
Nepal & & 1 & & 1 \\
Taiwan & & 1 & & 1 \\
Vietnam & & 3 & 1 & 1 \\
\hline Australia & 6 & 2 & & 10 \\
\hline Denmark & & 1 & & 1 \\
Finland & 1 & 1 & & 1 \\
Ireland & 1 & & \\
Norway & & &
\end{tabular}


Table 9. Cont.

\begin{tabular}{ccccc}
\hline Countries/Areas & Yes (Often) & Yes (Sometimes) & No & N of Responses \\
\hline Poland & & 1 & 1 \\
Spain & & 1 & 1 \\
Sweden & & 1 & 4 \\
Switzerland & & 3 & 1 \\
\hline Canada & 4 & 4 & 7 \\
US & 2 & 1 & 6 \\
\hline England & 2 & 7 & 3 \\
Scotland & 5 & 2 & 12 \\
UK-wide & 2 & & $N=59$ in 19 countries/areas \\
\hline
\end{tabular}

\subsubsection{School Gardening and Wildlife Areas}

Table 10 shows that school gardening appeared fairly well established as a form of outdoor learning across many countries/areas. Participants from Finland and Nepal did not report this form, which may perhaps reflect geographic or climatic barriers. Respondents from Ireland and Japan reported it as often used in their countries/areas. An advantage of this form is that the garden location can be based on school grounds, obviating any need for travel time, costs to engage with nature, or requirements of risk assessments for every visit [49].

Table 10. Prevalence of school gardening.

\begin{tabular}{ccccc}
\hline Countries/Areas & Yes (Often) & Yes (Sometimes) & No & Nof Responses \\
\hline Indonesia & 1 & 1 & & 1 \\
Japan & & 1 & 1 & 1 \\
Nepal & & 1 & & 1 \\
Taiwan & & & & 1 \\
Vietnam & & 3 & & 10 \\
\hline Australia & 7 & 2 & & 2 \\
\hline Denmark & & & 1 \\
Finland & 1 & 1 & & 1 \\
Ireland & & 1 & 1 \\
Norway & & 1 & & 1 \\
Poland & & 4 & 1 & 1 \\
Spain & & 1 & & 7 \\
Sweden & & 5 & & 5 \\
Switzerland & & 3 & & 3 \\
\hline Canada & 1 & 1 & & 12 \\
US & 2 & 5 & & $4=59$ in 19 countries/areas \\
\hline England & 1 & 1 & &
\end{tabular}

Gardens and wildlife areas may offer different sorts of affordances [49,50] for children's learning; Wells and Lekies [51] found both experiences positively affected subsequent pro-environmental attitudes, but only wild experiences influenced later pro-environmental behavior. In Table 11, we see the reported prevalence of wildlife areas within the school grounds in different nations. Providing wilder areas as part of the school grounds make biodiverse environments more easily accessible for learning purposes [52,53]. However, as one respondent in Australia commented, there might be safety 
reasons in some parts of the world that preclude leaving school grounds areas unmanaged. In some places, the cultural importance of the appearance of a school site may favor tidier grounds. It would be interesting to explore schools' reasons for including a wildlife area or not in further research.

Table 11. Prevalence of wildlife areas in school grounds.

\begin{tabular}{|c|c|c|c|c|}
\hline Countries/Areas & Common & Sometimes & Rarely & N of Responses \\
\hline Indonesia & 1 & & & 1 \\
\hline Japan & & 1 & & 1 \\
\hline Nepal & & 1 & & 1 \\
\hline Taiwan & & & 1 & 1 \\
\hline Vietnam & & & 1 & 1 \\
\hline Australia & 2 & 3 & 5 & 10 \\
\hline Denmark & & & 1 & 2 \\
\hline Finland & & & 1 & 1 \\
\hline Ireland & & 1 & & 1 \\
\hline Norway & 1 & & & 1 \\
\hline Poland & & & 1 & 1 \\
\hline Spain & & & 1 & 1 \\
\hline Sweden & & 2 & 1 & 3 \\
\hline Switzerland & & & 1 & 1 \\
\hline Canada & & 2 & 4 & 6 \\
\hline US & & 1 & 5 & 6 \\
\hline England & & 1 & 1 & 2 \\
\hline Scotland & 3 & 7 & 1 & 11 \\
\hline \multirow[t]{2}{*}{ UK-wide } & 2 & 2 & & 4 \\
\hline & & & & $N=55$ in 19 countries/areas \\
\hline
\end{tabular}

\subsubsection{Visits to Nature Reserves and National Parks}

Nature reserves were reported as often visited for outdoor learning in Ireland, Spain, and Denmark and sometimes visited in $67 \%$ of responding countries/areas. National parks were sometimes visited in $80 \%$ of countries/areas represented in the survey. These special places offer a different experience from the nearby nature of school gardens [54]. Maller suggested that a mixture of familiar places and progression to more remote highly valued natural environments may support children becoming connected to nature and engender later pro-environmental attitudes [55].

\subsection{Aligning Purposes and Forms}

Following up the suggestion that different forms support different outcomes, respondents were also asked which forms of outdoor learning they considered were most appropriate for particular outcomes. To indicate trends of association across countries/areas, the percentages of respondents choosing different options are shown in Table 12. In Table 12, the outcome most associated with each form is highlighted in darker grey, while the next perceived contribution of that form is highlighted in pale grey. From this, it is possible to see at a glance that encouraging healthy bodies and minds was considered by respondents as most supported by early years outdoor activities, outdoor and adventure education, and natural environment play; while developing social, confident, and connected people was regarded as most helped through outdoor and adventure education and early years outdoor activities. Embedded on-site curricular outdoor learning and Forest Schools together with early years activities were deemed important for stimulating creative self-regulated learners. In terms of supporting effective contributions and collaboration, school gardening was most selected, although embedded curricular outdoor learning was also associated with this outcome. Visits to national parks and nature reserves were very highly associated with underpinning care for others and the environment, although field studies and school gardening were also seen as linked with this outcome. 
Table 12. Aligning purposes and outcomes to forms of outdoor learning (across countries/areas).

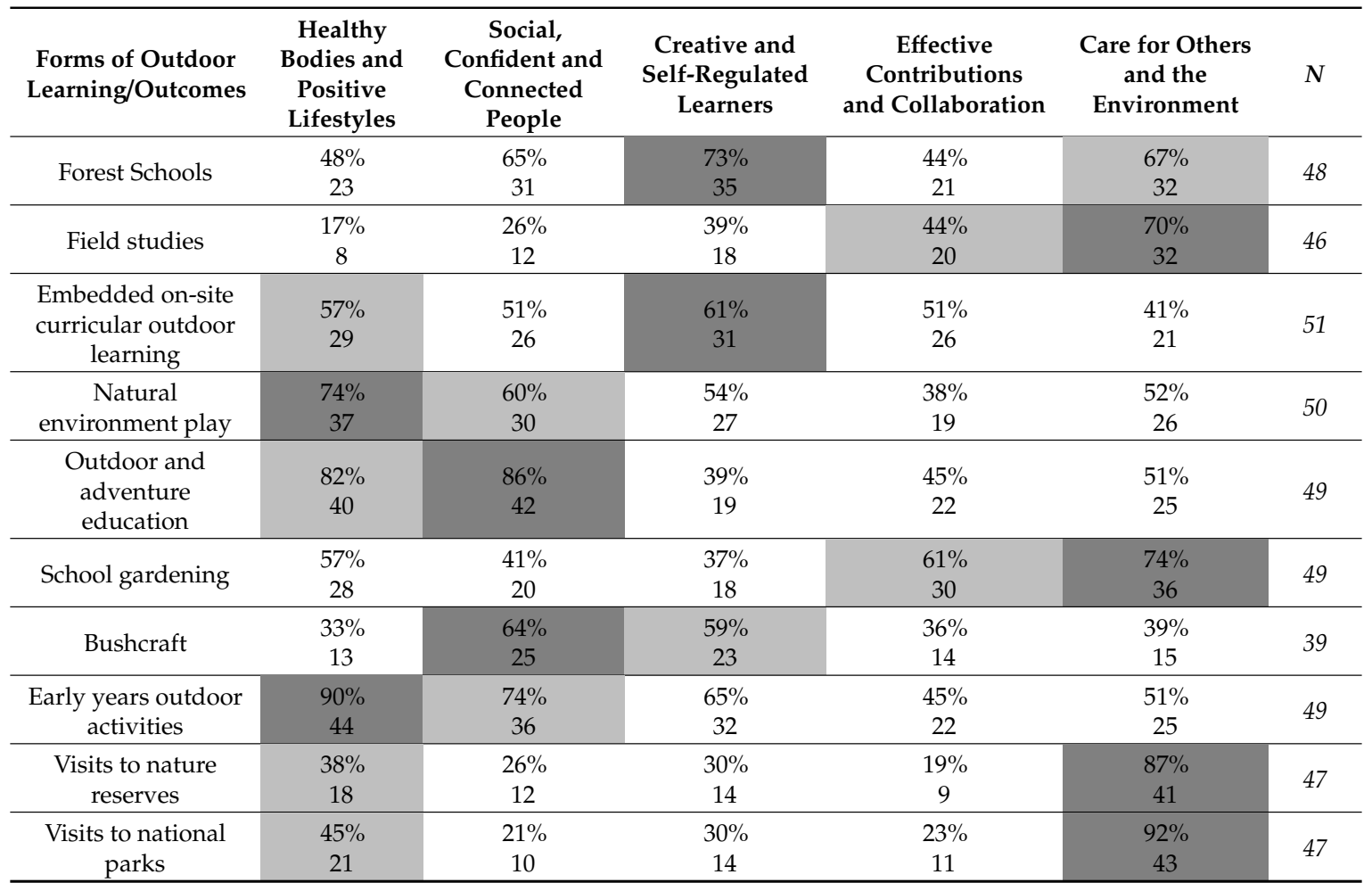

Table cells give percentages of respondents ticking each option in response to the question: Which of these drivers do you think are mainly behind the use of the different forms of learning? (Tick as many as apply). The outcome most associated with each form is highlighted in darker grey, while the next perceived contribution of that form is highlighted in pale grey.

From this analysis, it appears that some types of outdoor learning were more generalist in meeting various purposes, while others were more specialist in their impact. Field studies, for example, seemed less associated with health and well-being outcomes; outdoor and adventure education appeared particularly aligned with healthy living and the development of some inter- and intra-personal skills. In all the countries/areas, early years outdoor activities appeared to be the most valued for achieving across all the desired outcomes.

\subsection{Barriers to Outdoor Learning}

A number of barriers to outdoor learning were held in common across the nations represented in the survey. The barriers suggested in the questionnaire were derived from findings of the Natural Connections project [34] and earlier scoping of barriers by Kings College, London [33]. Table 13 is a summary table that shows the combined assessment of barriers across participating countries/areas, indicated by dark grey shading when the barrier was assessed as significant, light grey when it was considered significant to a degree, and white when it was not considered a barrier. We can see in this table that the most significant barriers internationally appeared to be linked to teacher training and how confident staff were in working outside and in linking the curriculum to outdoor activities. Lack of funding and the need for volunteer support were much less frequently regarded as significant barriers by respondents.

One respondent from Scotland echoed comments from some Australian respondents about staff unwillingness, suggesting,

Mindset-this is the key barrier.... It is remarkable that early years practitioners can enable outdoor learning and play on a daily basis and that outdoor nurseries are springing up 
everywhere demonstrating that all areas of the curriculum can happen outside yet primary and secondary colleagues feel unable to do the same.

Respondents in Ireland and Vietnam pointed to cultural resistance by teachers,

School-based learning is not so common in Vietnam due to curriculum and somehow difficult to change the traditional way of teaching and learning in the country/area (indoor learning). (respondent from Vietnam)

Education has had a formal, structured emphasis from its inception here for cultural and historical reasons possibly as a result of the context being a previously agrarian society. To a lesser extent, there seems to be a historical/cultural barrier where many educationally progressive initiatives were seen as part of a colonial education. (respondent from Ireland)

Three respondents from the UK and Canada also mentioned risk and health and safety concerns. Other factors included time and a lack of awareness of the potential benefits. These comments illustrate how cultural factors influence possibilities for future development of outdoor learning [3].

Table 13. Assessment of significance of barriers by respondents for their respective countries/areas.

\begin{tabular}{|c|c|c|c|c|c|}
\hline $\begin{array}{c}\text { Countries/Areas } \\
\text { Barriers }\end{array}$ & $\begin{array}{c}\text { Lacking } \\
\text { Confidence in } \\
\text { Working Outside }\end{array}$ & $\begin{array}{l}\text { Uncertainty } \\
\text { about Linking } \\
\text { to Curriculum }\end{array}$ & $\begin{array}{l}\text { Lack of } \\
\text { Funding }\end{array}$ & $\begin{array}{c}\text { Need for } \\
\text { Volunteer } \\
\text { Support }\end{array}$ & $N$ \\
\hline Indonesia & & & & & 1 \\
\hline Japan & & & & & 1 \\
\hline Taiwan & & & & & 1 \\
\hline Vietnam & & & & & 1 \\
\hline Australia & & & & & 10 \\
\hline Denmark & & & & & 1 \\
\hline Finland & & & & & 1 \\
\hline Ireland & & & & & 1 \\
\hline Poland & & & & & 1 \\
\hline Spain & & & & & 1 \\
\hline Sweden & & & & & 4 \\
\hline Switzerland & & & & & 1 \\
\hline Canada & & & & & 6 \\
\hline US & & & & & 6 \\
\hline England & & & & & 2 \\
\hline Scotland & & & & & 12 \\
\hline UK-wide & & & & & 4 \\
\hline $\begin{array}{c}\mathrm{N} \text { responses/ } \\
\text { countries/areas }\end{array}$ & 14 & 12 & 6 & 5 & $54 / 16$ \\
\hline
\end{tabular}

\subsubsection{Staff Lacking in Confidence in Working Outside}

Over three-quarters of respondents agreed this was a significant barrier (Table 14), indicating that attention was needed to train teachers and others tasked with outdoor learning in appropriate pedagogies for the outdoors. About two-thirds of countries/areas sometimes used external providers and these were expected to have expertise in the field. However, it was most common that teachers would lead outdoor learning across all countries/areas. Only some respondents in Australia, Canada, and the US reported that unpaid volunteers were usually involved in outdoor learning. In other countries/areas, they were sometimes involved, but in Denmark, Poland, Spain, Switzerland, and Vietnam, they were never used, according to the survey respondents. 
Table 14. Barriers to outdoor learning: Staff lacking confidence in working outside.

\begin{tabular}{|c|c|c|c|c|}
\hline Countries/Areas & Yes a Significant Barrier & To a Degree & Not a Barrier & Nof Responses \\
\hline Indonesia & & 1 & & 1 \\
\hline Japan & 1 & & & 1 \\
\hline Nepal & 1 & & & 1 \\
\hline Taiwan & 1 & & & 1 \\
\hline Vietnam & 1 & & & 1 \\
\hline Australia & 8 & 2 & & 10 \\
\hline Denmark & & 1 & & 1 \\
\hline Finland & 1 & & & 1 \\
\hline Ireland & 1 & & & 1 \\
\hline Norway & 1 & & & 1 \\
\hline Poland & 1 & & & 1 \\
\hline Spain & 1 & & & 1 \\
\hline Sweden & 3 & & & 3 \\
\hline Switzerland & 1 & & & 1 \\
\hline Canada & 4 & 2 & & 6 \\
\hline US & 5 & & 1 & 6 \\
\hline England & 2 & & & 2 \\
\hline Scotland & 8 & 4 & & 12 \\
\hline \multirow[t]{2}{*}{ UK-wide } & 2 & 2 & & 4 \\
\hline & & & & $N=55$ in 19 countries/areas \\
\hline
\end{tabular}

In Nepal, it was reported that, "School based outdoor activities are still at infancy in Nepal thus leaving great possibilities in this field. Awareness workshops thus play a pivotal role in pushing the barrier to a great extent in the meanwhile." The nations represented in the survey appeared at different points in their outdoor learning development. In Japan, creating natural infrastructure at schools was reported by the respondent as a priority:

School biotope (wildlife area esp. natural pond) became movement to create in Japan, but because of grounds maintenance and lack of knowledge of using the area, in many cases the area became unused. School gardening is common since it is mentioned in National Curriculum.

School ground infrastructure development was mentioned by expert commentators in several other countries/areas.

It seems many initial teacher training courses may have limited input on how to teach outside the classroom [56], which is unfortunate as the inclusion of modules for outdoor teaching and continuing professional development courses might help to increase teacher confidence. As one respondent from Scotland noted, "Time/of teachers to do continuing professional development (CPD) or something else in that area. Lack of resources and money, knowledge. No subject in school-based outdoor learning in teaching education/training" all potentially contribute to a lack of confidence. The Natural Connections project [34] found that an effective way of building teacher confidence in working outside was through practical sessions alongside more experienced colleagues.

However, there appeared little top-down support in the educational system for this in North America, where growth is attributed more to grassroots organizations' advocacy and support for schools. Even in Scotland, where policy promotes outdoor learning in a number of ways, one respondent commented that progress was happening, "Very gradually via the policies mentioned ... and many committed NGOs and others 'chipping away' at schools, encouraging and supporting them to take learning outdoors (via blogs, evidence etc.) to justify the place of outdoor learning (OL), training, networking etc." 


\subsubsection{Staff Uncertainty about Linking Outdoor Learning to the Curriculum}

A lack of ability to combine outdoor learning and unanticipated learning outcomes with teaching specific subject curriculum objectives was considered a barrier by most of the respondents (Table 15). As discussed earlier, this may depend to some extent on whether there were strong pressures on the delivery of curriculum content in that educational system.

Table 15. Barriers to outdoor learning: Staff uncertainty about linking outdoor learning and curriculum.

\begin{tabular}{|c|c|c|c|c|}
\hline Countries/Areas & Yes a Significant Barrier & To a Degree & Not a Barrier & N of Responses \\
\hline Indonesia & & 1 & & 1 \\
\hline Japan & 1 & & & 1 \\
\hline Nepal & 1 & & & 1 \\
\hline Taiwan & 1 & & & 1 \\
\hline Vietnam & 1 & & & 1 \\
\hline Australia & 8 & 1 & 1 & 10 \\
\hline Denmark & & 1 & & 1 \\
\hline Finland & 1 & & & 1 \\
\hline Ireland & & 1 & & 1 \\
\hline Norway & 1 & & & 1 \\
\hline Poland & 1 & & & 1 \\
\hline Spain & 1 & & & 1 \\
\hline Sweden & 3 & & & 3 \\
\hline Switzerland & 1 & & & 1 \\
\hline Canada & 5 & 1 & & 6 \\
\hline US & 5 & & 1 & 6 \\
\hline England & 1 & 1 & & 2 \\
\hline Scotland & 6 & 4 & 2 & 12 \\
\hline \multirow[t]{2}{*}{ UK-wide } & 2 & 2 & & 4 \\
\hline & & & & $N=55$ in 19 countries/areas \\
\hline
\end{tabular}

Although teachers may well be capable of mapping outdoor activities and their outcomes to the curriculum if they have sufficient time to undertake the necessary planning, time is a commodity which is often in short supply in schools [34]. Providing teachers with suitable prepared resources was felt helpful by a respondent from Australia to relieve time and curriculum pressures, "There are a few structured programs such as school kitchen gardens, which are easier to implement as they come with teaching resources." In Switzerland, a suite of resources across the curriculum was available for teachers to improve outdoor learning provision,

With our project 'Teaching Outdoors' which contains a manual for teaching all disciplines outdoors, with teacher training and a pilot study in coaching a few interested schools (www.draussenunterrichten.ch in German, www.enseignerdehors.ch in French).

\subsubsection{Lack of Funding}

According to most respondents, a lack of funding for outdoor learning was a barrier to some extent, but in some countries/areas, such as Indonesia, Taiwan, Poland, Canada, and the US, respondents considered it a significant one (Table 16). The reasons for this are probably multiple. For example, if outdoor learning is provided by external providers or at remote sites, this entails extra expenditure by schools or parents to enable that. Where outdoor learning is more embedded within educational practice and happens on or near the school site, the additional costs of children participating is likely to be lower with no expenditure on travel or center charges. However, providing progression from familiar to more remote and extraordinary natural environments with different learning possibilities will inevitably incur a financial cost. 
Table 16. Barriers to outdoor learning: Lack of funding.

\begin{tabular}{|c|c|c|c|c|}
\hline Countries/Areas & Yes a Significant Barrier & To a Degree & Not a Barrier & Nof Responses \\
\hline Indonesia & 1 & & & 1 \\
\hline Japan & & 1 & & 1 \\
\hline \multicolumn{5}{|l|}{ Nepal } \\
\hline Taiwan & 1 & & & 1 \\
\hline Vietnam & & 1 & & 1 \\
\hline Australia & 5 & 4 & 1 & 10 \\
\hline Denmark & & 1 & & 1 \\
\hline Finland & & 1 & & 1 \\
\hline Ireland & & & 1 & 1 \\
\hline \multicolumn{5}{|l|}{ Norway } \\
\hline Poland & 1 & & & 1 \\
\hline Spain & & 1 & & 1 \\
\hline Sweden & & 2 & 1 & 3 \\
\hline Switzerland & & 1 & & 1 \\
\hline Canada & 5 & 1 & & 6 \\
\hline US & 5 & & 1 & 6 \\
\hline England & & 1 & & 1 \\
\hline Scotland & 3 & 6 & 3 & 12 \\
\hline \multirow[t]{2}{*}{ UK-wide } & 2 & 2 & & 4 \\
\hline & & & & $N=52$ in 17 countries/areas \\
\hline
\end{tabular}

\subsubsection{Need for Volunteer Support}

As we see in Table 17 and have previously commented (Section 3.4.1), not all countries/areas involve volunteers in their outdoor learning provision, but requirements for high adult-to-children ratios to meet health and safety obligations for off-site visits and risk-averse societal attitudes may mean that parents and carers are needed to ensure compliance in many nations [57]. Community support can also extend possibilities for outdoor learning. In Indonesia, it was reported that parents and the society around the schools were also providers of outdoor learning; while in Finland, after-school clubs run by volunteers offered outdoor learning opportunities.

Table 17. Barriers to outdoor learning: Need for volunteer support.

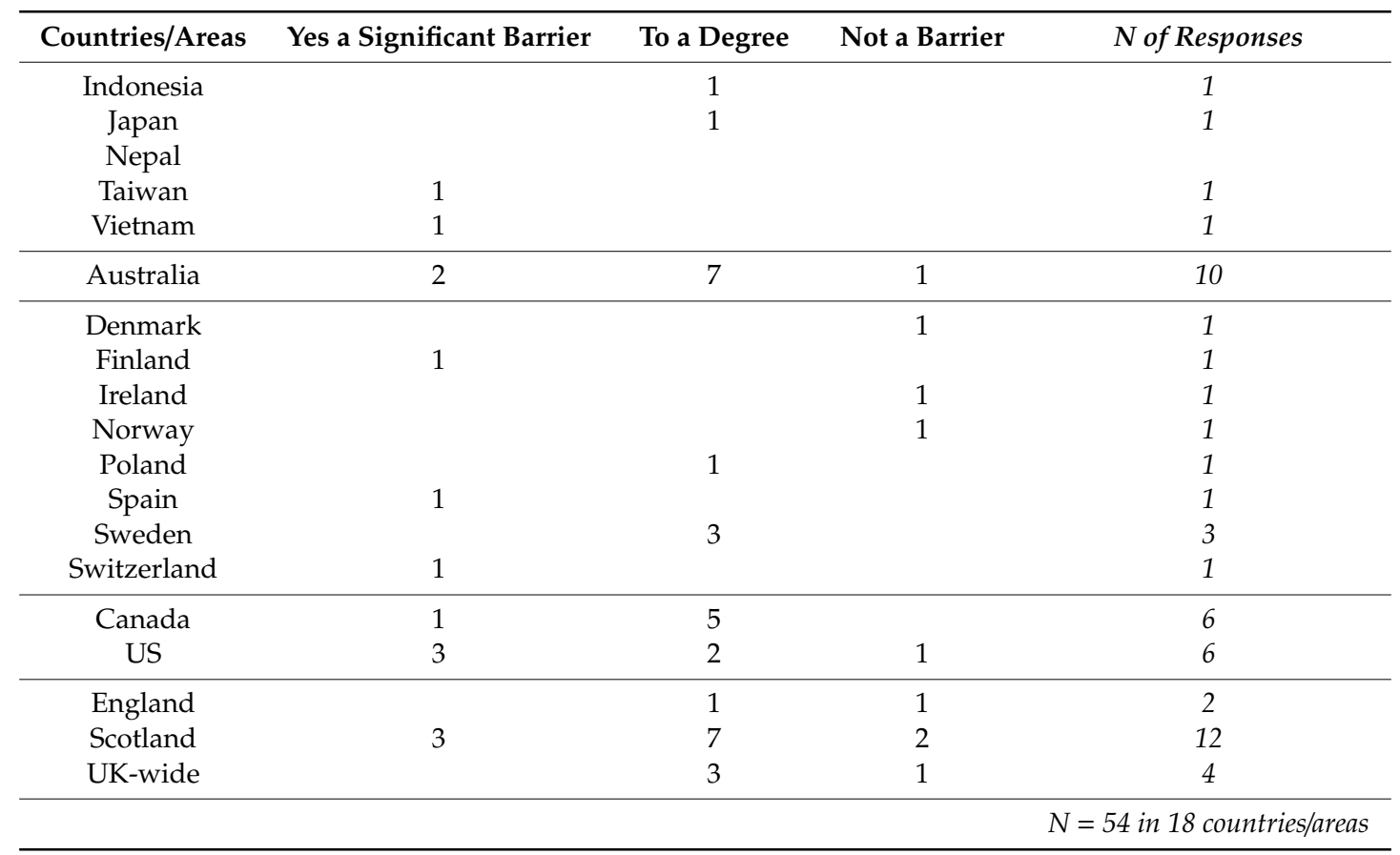




\section{Discussion}

In considering the responses from expert commentators across different countries/areas, we begin to appreciate how further work could contribute to addressing challenges associated with the development of school-based outdoor learning. The findings presented offer potential starting points for additional investigation. One possible method would be to develop a Delphi study, whereby ideas can be refined and contested within a panel of experts [35]. Another fruitful avenue might be in-depth national surveys to test the resonance of the impressions that emerged from this study situated within greater detail of policy, practice, and barriers in various national contexts. Local studies that include the children's perspectives on how outdoor learning affects their lives will also provide valuable insight into how various offers are received.

Countries/areas where respondents reported all five policy drivers as important were Indonesia, Taiwan, Finland, and Poland. In other places, the degree to which certain aspects were emphasized varied. According to the respondent from Japan, all drivers except for stimulating creative and self-regulating learners operated to a degree there; a similar situation to that reported in Vietnam, where developing social, confident, and connected people was also not considered a main driver. The respondent from Ireland suggested health outcomes were the main impetus, but that stimulating creative and self-regulated learners and supporting effective contributions and collaboration were not principal motivations for outdoor learning. In other countries/areas, the influence of policy drivers differed slightly in their relative emphases, but, in general, these drivers tended to be recognized across the nations. Explicit policy alignment would further facilitate the tailoring of outdoor learning programs to achieve desired goals.

From those countries/areas where more than one person responded, we can discern that there was not consensus about every aspect from the experts, so findings derived from individual reports and small numbers obviously need to be interpreted with caution. For example, within the multiple responses, it appeared that developing social, confident, and connected people and effective contributors and collaboration were main drivers in England, while in Scotland encouraging healthy bodies and positive lifestyles was more prominent. The two commentators responding about the UK as a whole reported that the care for others and the environment was the main driver. In Canada, it was reported that developing social, confident, and connected people was the principal motivation, whereas the US respondents placed equal emphasis on this and encouraging healthy bodies and positive lifestyles. Swedish respondents deemed health as a main motivator, but in neighboring Norway the respondent rated developing social, confident, and connected people more highly. Finally, in Australia, all aims were highly rated with considerable consensus across participants, but health, stimulating creative and self-regulated learners, and care for others and the environment were the top priorities. Inevitably, local enactments and the position of the expert as policy maker, academic, or practitioner will shape opinions, but exploring such variation would support future collaborations to achieve greater consensus around intent, implementation, and impact [58] and clearer theories of change.

These impressions and insights into the state of play for school-based outdoor learning across different countries/areas provide considerable food for thought to support that endeavor. The number of expert commentators responding to the survey demonstrated that the wealth of evidence for benefits from spending time in nature is in some respects well established in these countries/areas. However, all described challenges in embedding outdoor learning within their educational systems, and countries/areas appeared to be at different stages of development. For some, the challenge lay in cultural and material barriers, where the first steps may need to be awareness raising about the benefits to policy makers, practitioners, and the general public [59] or constructing infrastructure to support forms of outdoor learning that are accessible and affordable [34,52,59]. For others, dominant performativity culture in their countries/areas meant that persuading school staff to make space for outdoor learning in busy content-driven curricular timetabling remained a hurdle [42]. Encouragingly, the main challenge seemed to be about changing mindsets rather than a lack of funding per se, and this cultural change can be achieved through on the job professional development training and 
experience [34]. At a national level, research and development efforts might profitably be directed towards identifying and understanding how to overcome specific challenges in a logical sequence appropriate to their context.

The alignment of forms of outdoor learning and purposes revealed some indications of how provision might be better tailored to address specific desired outcomes according to priorities, both at a national policy level and within schools themselves. Without regularity of curriculum-based learning outside the classroom, occasional forms of outdoor learning remain vulnerable to changes in priorities and external pressures [42]. Early years outdoor activities and on-site outdoor learning linked to the curriculum seemed to contribute to some degree to all desired outcomes across the board and could comprise a minimum baseline of entitlement provision. A global priority to protect children's health and well-being and glaring inequalities in relation to this [8] also provide a compelling rationale for these methods to offer wider participation in the benefits of spending time in nature [7], and the additional provision of opportunities for outdoor and adventure education during schooling will make substantial contributions towards this goal. Sustainability agendas appeared to underpin strong motivation for promoting outdoor learning in many countries/areas, whether at governmental or personal levels $[7,52,53,59]$, and national parks and nature reserves were considered especially effective for inculcating care for others and the environment. Inclusion of visits to areas rich in biodiversity as part of children's experience at school will help to meet this aim. In short, increasing the awareness of policy drivers and promoting the most effective forms of outdoor learning to achieve them can refine how school-based outdoor learning is planned and operationalized at international, national, regional, and local levels.

For teachers in some countries/areas, having a policy directive to include more outdoor learning as an integrated element of curriculum delivery would give them permission to make room for it [7], although some teachers may still lack confidence and time to plan for this [34]. Having training and experiences in working outside is an effective tool to overcome personal resistance, and team teaching or on-site continuing professional development can be transformative [34], but equally high-quality resources can provide a valuable starting point for local adaptations. A recent set of books has linked the English primary national curriculum objectives for every subject to progressions in outdoor learning to save teachers planning time and provide a springboard for increasing curriculum-based outdoor learning [60]. They have subsequently been adapted for the Scottish Curriculum for Excellence, and there are plans for further "translations" to other national curricula. Whether time, experience, or funds represent barriers, the development of suitable outdoor learning environments within the school grounds can facilitate a range of experiences on teachers' doorsteps without the need for travel time and costs, the additional paperwork of repeated risk assessments, or the incurring of external provider fees $[34,47,52,53]$.

Several commentators mentioned that inclusion of outdoor learning and its priority varied regionally and at a local level in their country/area, so assessing patterns across whole countries/areas is not clear cut. The interpretation of what outdoor learning might look like varied from macrogovernmental and cultural influences through institutional expectations and affordances to the personal values and expertise of individuals within schools [42]. As noted earlier, further drilling down at a national level into the interface of policies, practice, and learning experiences within different forms of outdoor learning would help unpack some of this complexity and enhance international comparisons and development. An international project is currently underway to explore key terms, definitions, taxonomies, and ontologies related to outdoor experiences, based on a scoping literature review and collaboration of international experts in the field through analysis and discussion. This process is working towards conceptual models that can speak across nations [2]. This ambition exceeds the possibilities of this small explorative study. Nonetheless, the research has highlighted some potential ways forward for the field.

Suggestions that respondents made about how improvements could be made to school-based outdoor learning included the support of: grassroots teacher-led movements (Ireland); the Children in 
Nature network (US); continuing professional development, teacher education and collective provision (Australia, England, Scotland, Sweden, Switzerland); school grounds infrastructure development (Sweden, US, Japan); and outdoor learning being enshrined in educational policy, teachers' registration and professional recognition (Denmark, Norway, Scotland). Figure 1 summarizes some possible actions that warrant consideration at national and local levels to support the development of school-based outdoor learning.

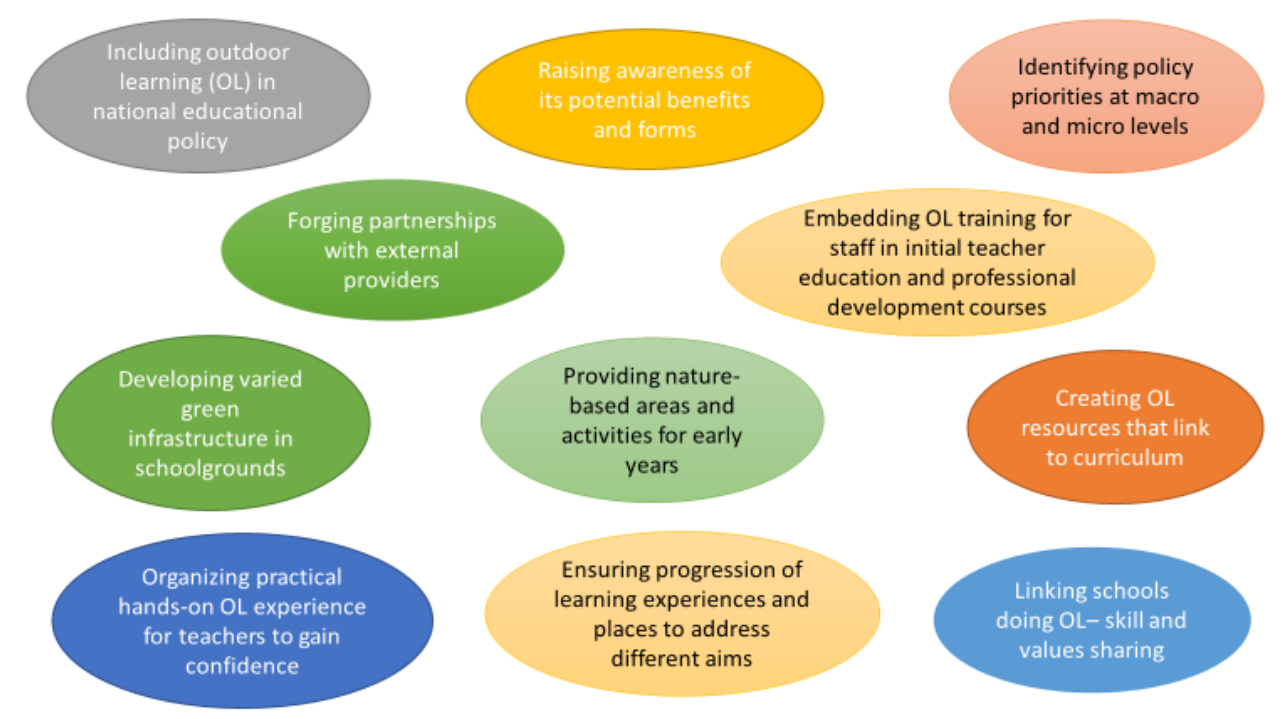

Figure 1. Possible actions in developing school-based outdoor learning.

\section{Conclusions}

Although this research is limited in that it is based on a small sample (80) of expert commentators on outdoor learning and can therefore only paint an impressionistic picture, nevertheless, it may hopefully serve to open international discussion further about how outdoor learning provision might be embedded within schools through consideration of other experiences. By highlighting differences as well as commonalities for this special issue on trends in the field of outdoor and adventure education, the danger of policy borrowing without contextual sensitivity may be lessened, but it is beyond the scope of this paper to provide detailed explanation of educational, cultural, and material contexts represented within this survey. Attention in research and policy development to the wider cultural influences that impinge on policy and practice will aid careful interpretation and the transfer of ideas between contexts. Further research is also needed to gain insight into the outcomes and purposes that the children experiencing different forms of outdoor learning themselves perceive and value. This will support greater nuance in how national and local provision might be shaped to provide progression towards outcomes and maintain personal and societal benefits for young people. We should also reflect upon the failure of some research within the rich arena of literature to convince policy makers at different levels to endorse embedded school-based forms of outdoor learning, so that studies can be designed to address that gap [24], if we are to maximize the value that outdoor learning can have for young people's present and future lives.

Funding: This research was funded by The Wildlife Trusts, UK, and informed by research funded by the Economic and Social Research Council, UK, grant number ES/J019445/1, and the Department for the Environment, Food and Rural Affairs, UK, Natural England and Historic England.

Acknowledgments: The Wildlife Trusts have kindly given permission for the publication of this article arising from the results of the commissioned research. Thanks are also due to all the experts in outdoor learning who contributed to the survey and to my colleagues in earlier contributory research projects referenced below.

Conflicts of Interest: The author declares no conflict of interest. The funders had no role in the design of the study; in the collection, analyses, or interpretation of data; or in the writing of the manuscript. 


\section{Appendix A}

International review of purposeful outdoor learning in schools A survey on behalf of the UK Wildlife Trusts

1. Survey of expert commentators about purposeful practice in school-based outdoor learning.

There is a wealth of evidence about the benefits for children of spending time outside, but less understanding of how different forms of school-based outdoor learning can support specific positive outcomes. This survey is an important part of a programme to help inform this gap in knowledge.

In this survey we are defining school-based outdoor learning as play, teaching and learning that takes place in natural environments for children in formal education and care settings.

Findings will be shared with participants and other relevant organisations.

The survey starts by asking you about motivations and purposes. Then you are asked to link them to forms of outdoor learning in schools. Next there are some questions about how widespread and frequent outdoor learning is in your country. Finally you are asked to submit a vignette, if you wish to, and illustrative photographs (if you have permission to publish).

The questions will take about 10 minutes to answer, plus time to add in information about any vignettes you describe for us.

Thank you for taking part. Please submit your answers by Friday 22 September 2017.

1. Please enter the name of the country (and region/state if appropriate) you will be providing information about: 
International review of purposeful outdoor learning in schools A survey on behalf of the UK Wildlife Trusts

2. Drivers

The drivers/purposes in the list below were identified in Malone, K. and Waite, S. (2016) Student Outcomes and Natural Schooling. Plymouth: Plymouth University. Available at http://www.plymouth.ac.uk/research/oelres-net.

1. What do you think are the main drivers for school-based outdoor learning in your country?

Yes

To a degree

No

Encouraging healthy
bodies and positive

lifestyles

Developing social,

confident and connected

people

Stimulating self-

regulated and creative

learners

Supporting effective

contributions and

collaboration

Underpinning care and

action for others and the

environment.

Other (please specify)

2. Is there any government policy which enables school-based outdoor learning in your country?
Yes
To a degree
No

Please comment and, if possible, provide a link to relevant policy.

Figure A1. Cont 
International review of purposeful outdoor learning in schools

A survey on behalf of the UK Wildlife Trusts

wildlife

TRUSTS

3. Forms of learning

1. Which forms of outdoor learning are used in your country?

Forest Schools
Field studies
Embedded on-site
curricular outdoor
learning
Natural environment play
Outdoor and adventure
education
School gardening
Bushcraft
Early years outdoor
activities
Visits to nature reserves
Visits to national parks

Other (please specify)

Figure A1. Cont. 


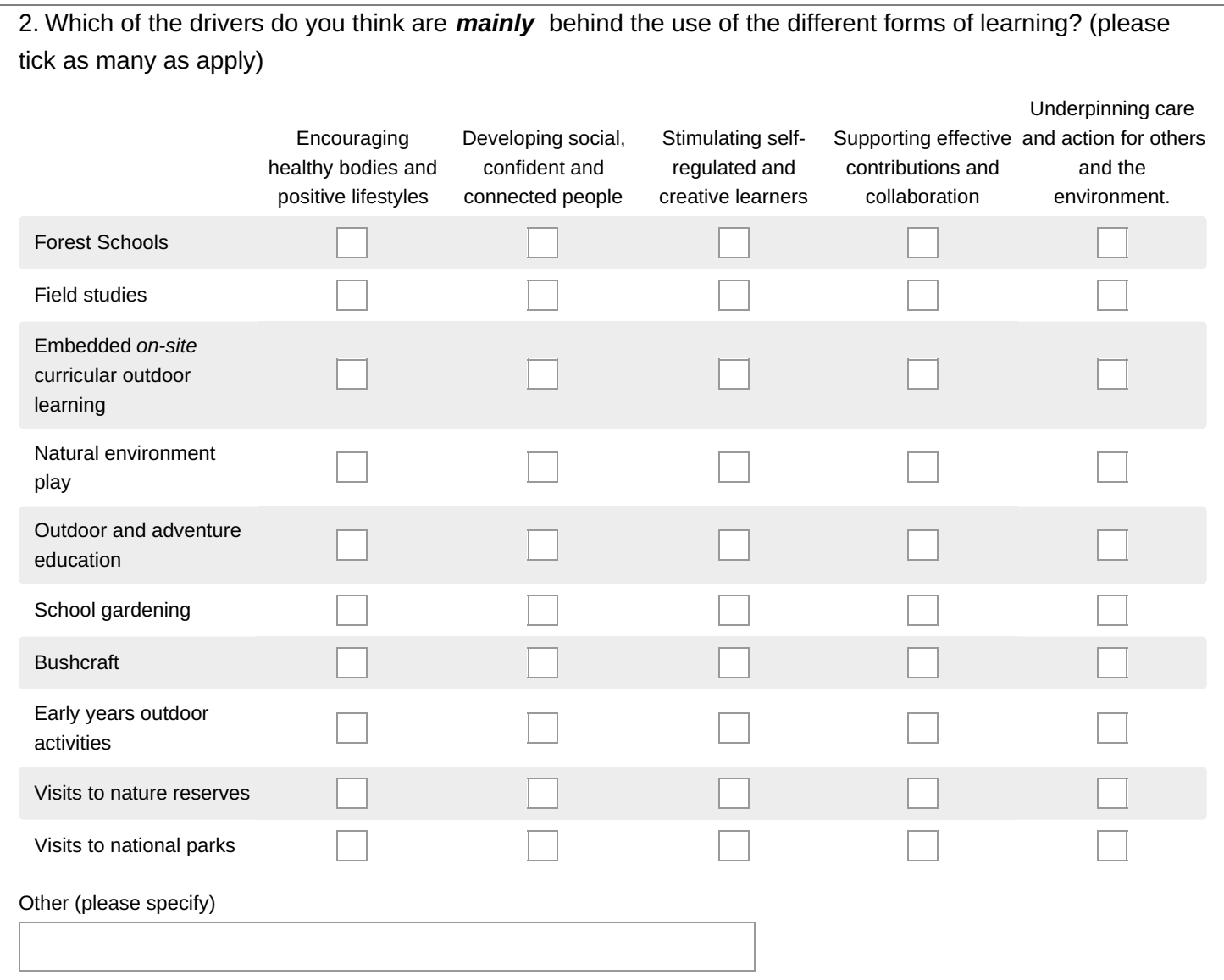

Figure A1. Cont. 
International review of purposeful outdoor learning in schools

A survey on behalf of the UK Wildlife Trusts

4. Provision

1. Who provides outdoor learning in schools?

\begin{tabular}{l} 
Teachers \\
Teaching assistants \\
External business \\
organisations - paid \\
Charitable organisations \\
- paid \\
Charitable organisations \\
- free of charge \\
Unpaid volunteers \\
Other types of provider (please describe) \\
\hline
\end{tabular}

2. How common is it for school grounds to have a wildlife area in your country?
Common
Sometimes
Rarely

Please comment if you wish

Figure A1. Cont. 
3. To what extent are there barriers to school-based outdoor learning in your country?

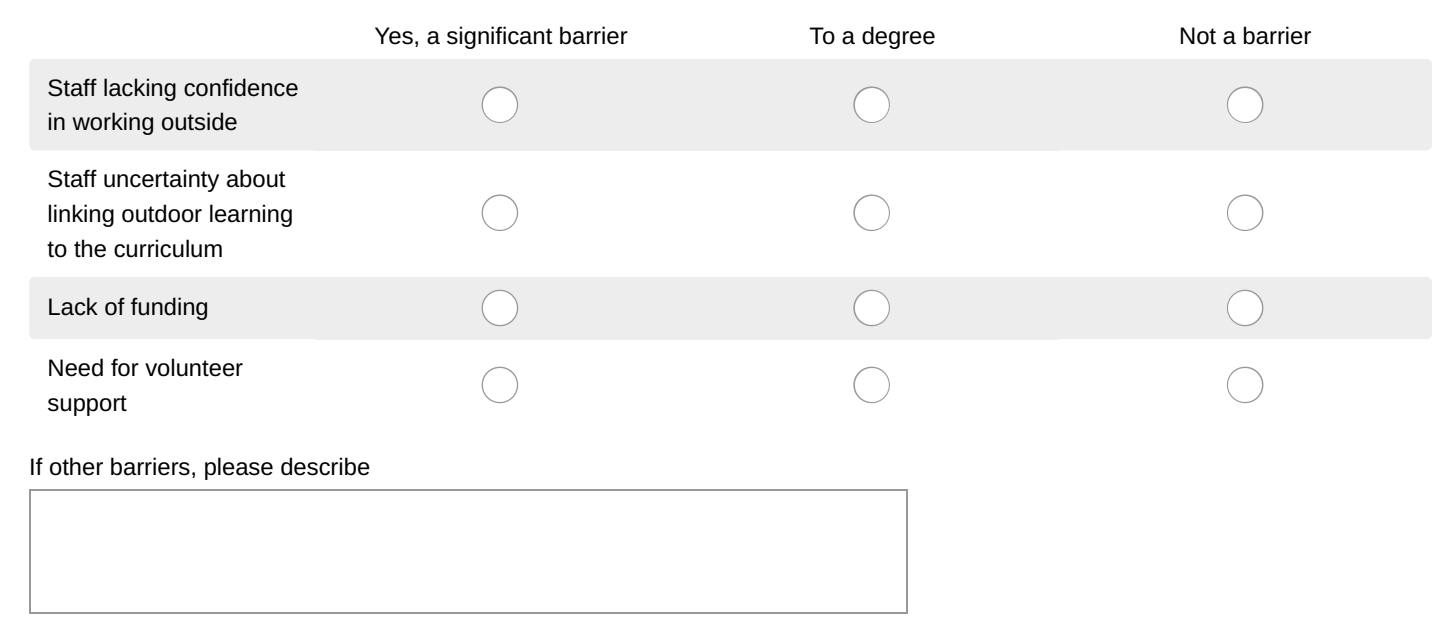

4. Please briefly describe how improvements in school-based outdoor learning are being addressed in your country.

Figure A1. Cont. 


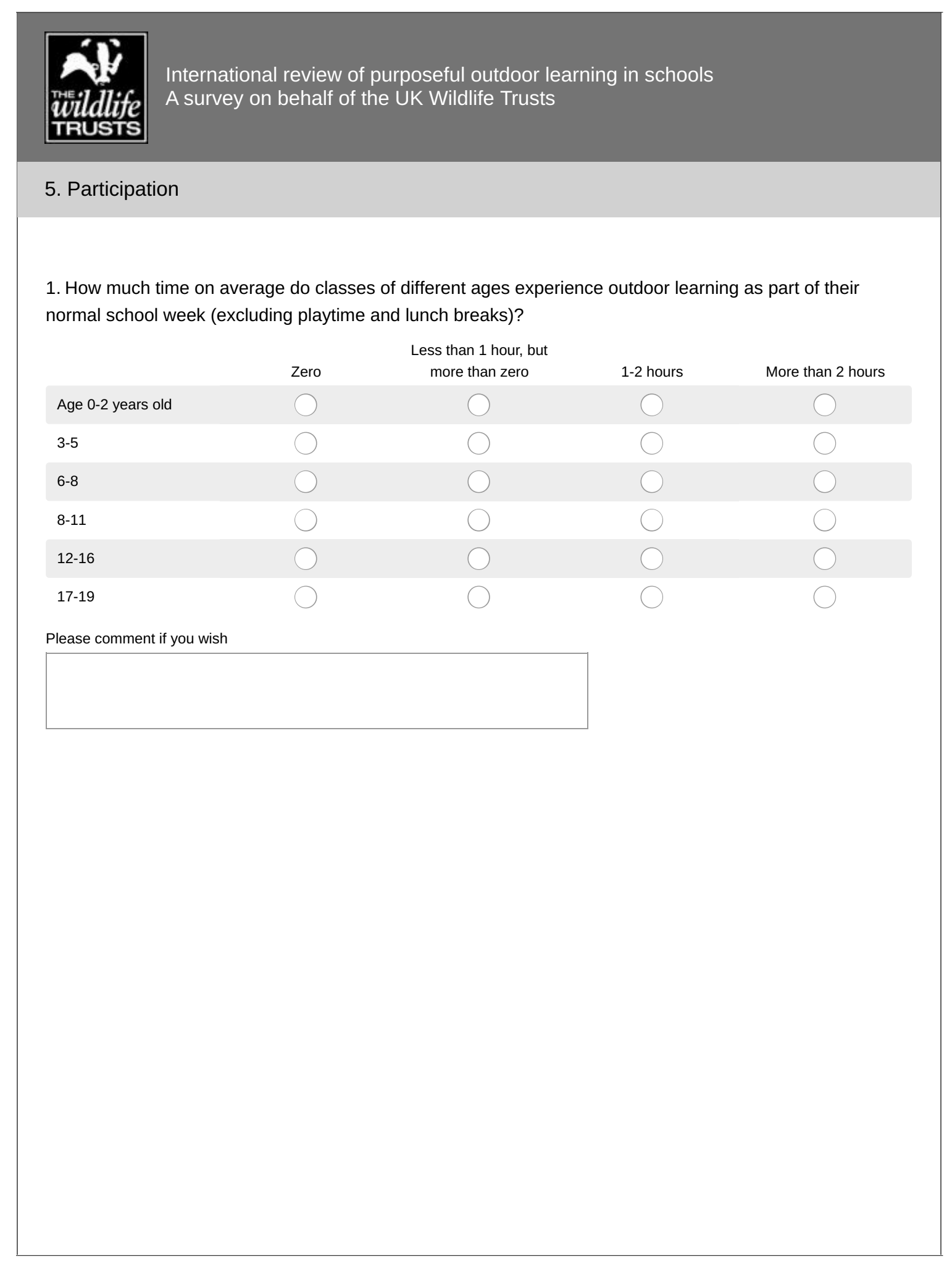

Figure A1. Cont. 
International review of purposeful outdoor learning in schools

A survey on behalf of the UK Wildlife Trusts

millat

TRUSTS

6. Vignette

1. If possible, please provide a vignette that illustrates an exemplary case of outdoor learning in your country, including any policy drivers, its purpose, the activity and its location.

2. Will you be sending any extra vignette material to sjwaite@plymouth.ac.uk?

Yes

No

Figure A1. The questionnaire. 
International review of purposeful outdoor learning in schools A survey on behalf of the UK Wildlife Trusts

\section{TRUSTS}

\section{About you}

1. Please enter your details if you are willing for us to follow up any queries with you.

Name

Job title

email

phone

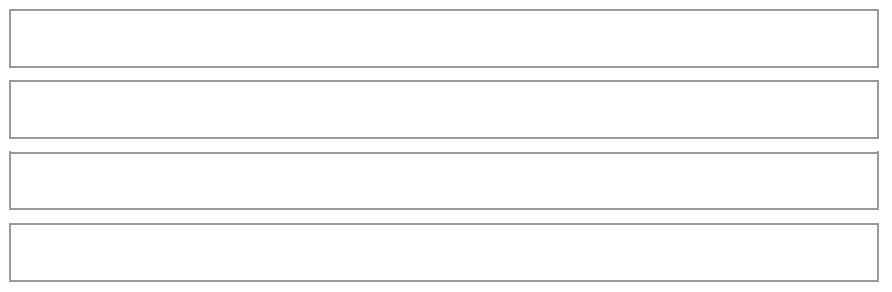

2. Please briefly describe your role regarding outdoor learning.

3. How qualified do you feel to provide the information about outdoor learning in your country that we have asked for in this questionaire?
Well qualified to answer
Fairly well
Not very well

4. Please add any further comments you wish to make in the box.

Figure A1. The questionnaire. 


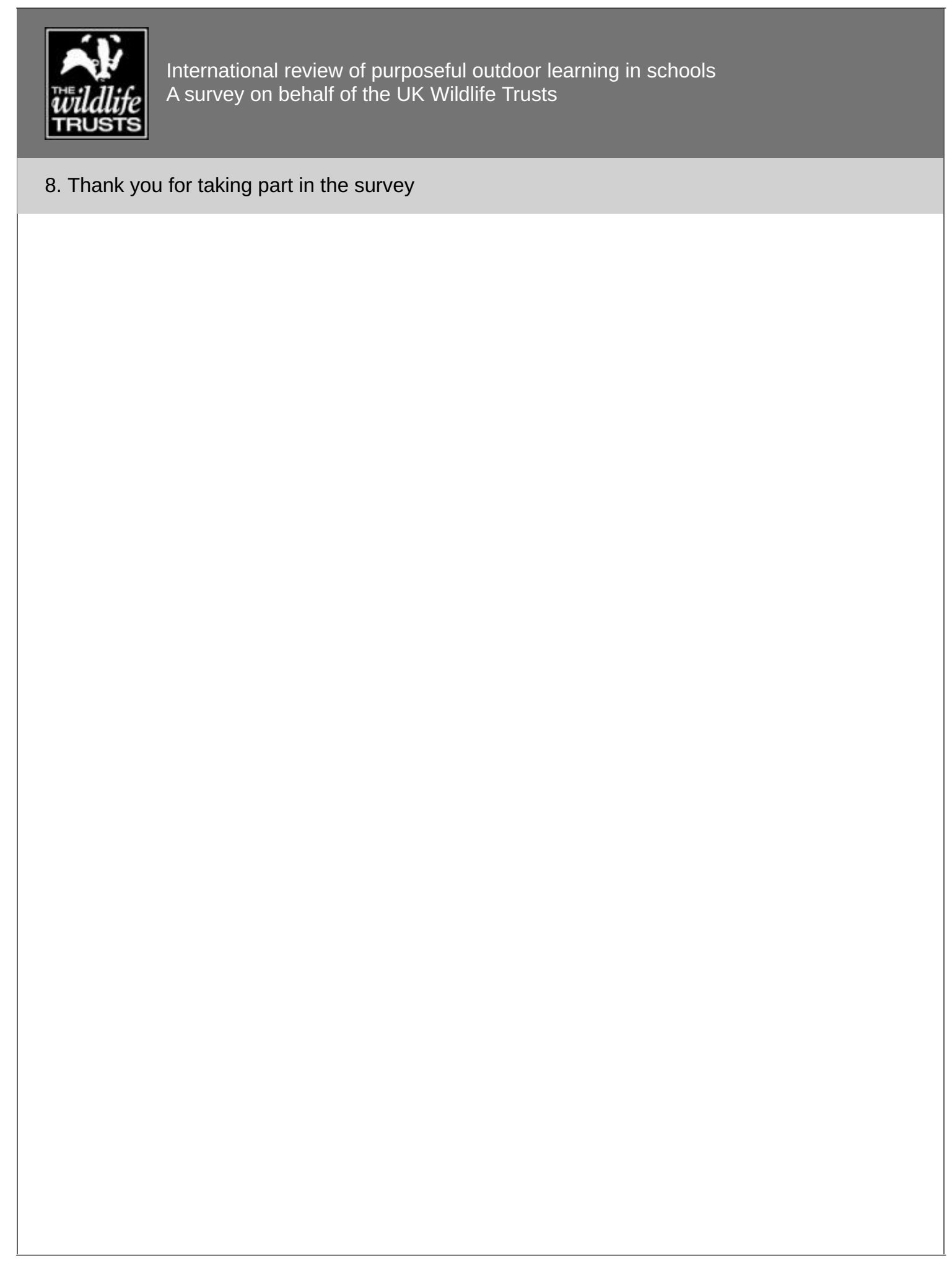

Figure A1. The questionnaire. 


\section{References}

1. Waite, S.; Bølling, M.; Bentsen, P. Comparing apples and pears? A conceptual framework for understanding forms of outdoor learning through comparison of English Forest Schools and Danish udeskole. Environ. Educ. Res. 2016, 22, 868-892. [CrossRef]

2. PLaTO-Net Harmonization Project. Available online: https://www.outdoorplaycanada.ca/plato-net/ (accessed on 29 October 2020).

3. Bentsen, P.; Ho, S.; Gray, T.; Waite, S. A global view of learning outside the classroom. In Children Learning Outside the Classroom: From Birth to Eleven, 2nd ed.; Waite, S., Ed.; SAGE: London, UK, 2017.

4. Passy, R.; Bentsen, P.; Gray, T.; Ho, S. Integrating outdoor learning into the curriculum: An exploration in four nations. Curric. Perspect. 2019, 39, 73-78. [CrossRef]

5. Brookes, A. Gilbert White never came this far South. Naturalist knowledge and the limits of universalist environmental education. Can. J. Environ. Educ. 2002, 7, 73-87.

6. Rogers, S.; Evans, J. Inside Role Play in Early Childhood Education: Researching Children's Perspectives; Routledge: London, UK, 2008.

7. Malone, K.; Waite, S. Student Outcomes and Natural Schooling: Pathways from Evidence to Impact Report. 2016. Available online: https://www.plymouth.ac.uk/uploads/production/document/path/6/6811/Stude nt_outcomes_and_natural_schooling_pathways_to_impact_2016.pdf (accessed on 18 September 2020). [CrossRef]

8. United Nations. Convention of the Rights of the Child. 1989. Available online: https://downloads.unicef.o rg.uk/wp-content/uploads/2010/05/UNCRC_united_nations_convention_on_the_rights_of_the_child.pdf (accessed on 26 September 2020).

9. Marmot, M. Fair Society, Healthy Lives: The Marmot Review: Strategic Review of Health Inequalities in England Post 2010; University College London: London, UK, 2010.

10. Paterson, C.; Tyler, R.; Lexmond, J. Character and Resilience Manifesto; The All Party Parliamentary Group (APPG) on Social Mobility: London, UK, 2014; Available online: http://www.centreforum.org/assets/pubs/ch aracter-and-resilience.pdf (accessed on 12 October 2020).

11. The Future of Work: Jobs and Skills in 2030. Available online: https://assets.publishing.service.gov.uk/gover nment/uploads/system/uploads/attachment_data/file/303335/the_future_of_work_key_findings_edit.pdf (accessed on 12 October 2020).

12. Her Majesty's Government. A Green Future: Our 25 Year Plan to Improve the Environment. 2018. Available online: https://www.gov.uk/government/publications/25-year-environment-plan (accessed on 28 October 2020).

13. Curriculum for Excellence. Available online: https://education.gov.scot/documents/All-experiencesoutcomes 18.pdf (accessed on 19 September 2020).

14. Living Sustainably: The Australian Government's National Action Plan for Education for Sustainability. Available online: https://www.iau-hesd.net/sites/default/files/documents/2009_-_living_sustainably_t he_australian_governments_national_action_plan_for_education_for_sustainability_fr.pdf (accessed on 12 October 2020).

15. Education for Sustainable Development in Japan. Available online: https://www.nier.go.jp/English/educati onjapan/pdf/201103ESD.pdf (accessed on 26 September 2020).

16. MacQuarrie, S.; Nugent, C.; Warden, C. Learning with nature and learning from others: Nature as setting and resource for early childhood education. J. Adventure Educ. Outdoor Learn. 2015, 15, 1-23. [CrossRef]

17. Rea, T.; Waite, S. International perspectives on outdoor and experiential learning. Education 2009, 37, 1-4. [CrossRef]

18. Waite, S.; Pleasants, K. Cultural Perspectives on Experiential Learning in Outdoor Spaces. J. Adventure Educ. Outdoor Learn. 2012, 12, 161-165. [CrossRef]

19. Leather, M. A critique of Forest School: Something lost in translation. J. Outdoor Environ. Educ. 2018, 21, 5-18. [CrossRef]

20. Waite, S. Outdoor Learning Research: Insight into Forms and Functions; Routledge: Abingdon, UK, 2019.

21. Rickinson, M.; Dillon, J.; Teamey, K.; Morris, M.; Choi, M.Y.; Sanders, D.; Benefield, P. A Review of Research on Outdoor Learning; National Foundation for Educational Research: Slough, UK, 2004. 
22. Malone, K. Every Experience Matters: An Evidence based Research Report on the Role of Learning Outside the Classroom for Children's Whole Development from Birth to Eighteen Years; Farming and Countryside Education for UK Department Children, School and Families: Wollongong, Australia, 2008.

23. Gill, T. Children and Nature: A Quasi-Systematic Review of the Empirical Evidence; Sustainable Development Commission: London, UK, 2011.

24. Fiennes, C.; Oliver, E.; Dickson, K.; Escobar, D.; Romans, A.; Oliver, S. The Existing Evidence-Base about the Effectiveness of Outdoor Learning. 2015. Available online: https://www.outdoor-learning.org/Portals/0/IOL\%2 0Documents/Research/outdoor-learning-giving-evidence-revised-final-report-nov-2015-etc-v21.pdf?ver=2 017-03-16-110244-937 (accessed on 18 September 2020).

25. Dillon, J.; Dickie, I. Learning in the Natural Environment: Review of Social and Economic Benefits and Barriers. Number 092. Natural England Commissioned Report 092. 2012. Available online: http://publications.natural england.org.uk/publication/1321181 (accessed on 18 September 2020).

26. Waite, S. Losing our way?: Declining outdoor opportunities for learning for children aged between 2 and 11 . J. Adventure Educ. Outdoor Learn. 2010, 10, 111-126. [CrossRef]

27. Mullan, K. A Child's Day: Trends in Time use in the UK from 1975 to 2015. Br. J. Sociol. 2018, 70, 997-1024. [CrossRef]

28. McCabe, S. Family leisure, opening a window on the meaning of family. Ann. Leis. Res. 2015, 18, 175-179. [CrossRef]

29. Louv, R. Last Child in the Woods; Algonquin Books of Chapel Hill: New York, NY, USA, 2010.

30. White, M.P.; Alcock, I.; Grellier, J.; Wheeler, B.W.; Hartig, T.; Warber, S.L.; Bone, A.; Depledge, M.H.; Fleming, L.E. Spending at least 120 minutes a week in nature is associated with good health and wellbeing. Sci. Rep. 2019, 9, 7730. [CrossRef]

31. Gutman, L.M.; Schoon, I. A Synthesis of Causal Evidence Linking Non-Cognitive Skills to Later Outcomes for Children and Adolescents. In Non-Cognitive Skills and Factors in Educational Attainment. Contemporary Approaches to Research in Learning Innovations; Khine, M.S., Areepattamannil, S., Eds.; Sense Publishers: Rotterdam, The Netherlands, 2016. [CrossRef]

32. Robson, C. Real World Research, 3rd ed.; John Wiley \& Sons Ltd: Chichester, UK, 2011.

33. Beyond Barriers to Learning Outside the Classroom in Natural Environments. Available online: http: //publications.naturalengland.org.uk/file/6621187224371200 (accessed on 21 September 2020).

34. Waite, S.; Passy, R.; Gilchrist, M.; Hunt, A.; Blackwell, I. Natural Connections Demonstration Project 2012-2016: Final Report; Natural England: York, UK, 2016; Available online: http://publications.naturalengland.org.uk/p ublication/6636651036540928 (accessed on 16 September 2020).

35. Okoli, C.; Pawlowski, S.D. The Delphi Method as a Research Tool: An Example, Design Considerations and Applications. Inf. Manag. 2004, 42, 15-29. [CrossRef]

36. Waite, S. Purposeful Practice in School-Based Outdoor Learning; The Wildlife Trusts: Newark, UK, 2017.

37. Growing the Udeskole Movement. Available online: https://www.childrenandnature.org/2017/04/ 06/growing-the-udeskole-movement-finding-balance-in-school-based-outdoor-learning-2/ (accessed on 19 September 2020).

38. Ogilvie, K.C. Roots and Wings: A History of Outdoor Education and Outdoor Learning in the UK; Russell House Publishing: Lyme Regis, UK, 2013; ISBN 978-1-905541-84-3.

39. English Outdoor Council. High Quality Outdoor Learning. 2015. Available online: http://www.englisho utdoorcouncil.org/wp-content/uploads/2049-High-quality-outdoor-learningweb-version.pdf (accessed on 20 September 2020).

40. The National Curriculum in England: Framework for Key Stages 1-4. Available online: https://www.gov.uk /government/publications/national-curriculum-in-england-framework-for-key-stages-1-to-4 (accessed on 19 September 2020).

41. Learning for Sustainability. Available online: https:/education.gov.scot/education-scotland/scottish -education-system/policy-for-scottish-education/policy-drivers/learning-for-sustainability/ (accessed on 19 September 2020).

42. Waite, S. Teaching and learning outside the classroom: Personal values, alternative pedagogies and standards. Education 2010, 39, 65-82. [CrossRef]

43. Nature Friendly Schools. Available online: https://www.naturefriendlyschools.co.uk/\#: \{\}:text=Nature\%20 Friendly\%20Schools\%20is\%20a,(DEFRA)\%20and\%20Natural\%20England (accessed on 19 September 2020). 
44. Knight, S. International Perspectives on Forest School; Natural Spaces to Play and Learn; SAGE: London, UK, 2013.

45. What Is Forest School? Available online: https://www.forestschoolassociation.org/what-is-forest-school/ (accessed on 20 September 2020).

46. JOEE Special Issue: Forest School. 2018. Available online: https://outdooreducationaustralia.org.au/library /march-2018-joee/ (accessed on 20 September 2020).

47. Barfod, K.; Ejbye-Ernst, N.; Mygind, L.; Bentsen, P. Increased provision of udeskole in Danish schools; An updated national population survey. Urban For. Urban Green. 2016, 20, 277-281. [CrossRef]

48. Gurholt-Pedersen, K. Joy of nature, friluftsliv education and self: Combining narrative and cultural-ecological approaches to environmental sustainability. J. Adventure Educ. Outdoor Learn. 2014, 14, 233-246. [CrossRef]

49. Passy, R. School gardens: Teaching and learning outside the front door. Education 2014, 42, 23-38. [CrossRef]

50. Mawson, W.B. Experiencing the 'wild woods': The impact of pedagogy on children's experience of a natural environment. Eur. Early Child. Educ. Res. J. 2014, 22, 513-524. [CrossRef]

51. Wells, N.M.; Lekies, K.S. Nature and the Life Course: Pathways from Childhood Nature Experiences to Adult Environmentalism. Child. Youth Environ. 2006, 16, 1-24.

52. Almers, E.; Askerlund, P.; Samuelsson, T.; Waite, S. Children's preferences for schoolyard features and understanding of ecosystem service innovations-A study in five Swedish preschools. J. Adventure Educ. Outdoor Learn. 2020. [CrossRef]

53. Hammarsten, M.; Askerlund, P.; Almers, E.; Avery, H.; Samuelsson, T. Developing ecological literacy in a forest garden: Children's perspectives. J. Adventure Educ. Outdoor Learn. 2018, 19, 227-241. [CrossRef]

54. Carson, R. The Sense of Wonder; HarperCollins: New York, NY, USA, 1965.

55. Maller, C.J. Promoting children's mental, emotional and social health through contact with nature: A model. Health Educ. 2009, 109, 522-543. [CrossRef]

56. Prince, H.E. Changes in outdoor learning in primary schools in England, 1995 and 2017: Lessons for good practice. J. Adventure Educ. Outdoor Learn. 2019, 19, 329-342. [CrossRef]

57. The Risk in Play Declaration, International School Grounds Alliance. 2017. Available online: https: //www.internationalschoolgrounds.org/risk (accessed on 26 September 2020).

58. Submission from Scottish Advisory Panel for Outdoor Education to the Education and Culture Committee of the Scottish Government on Outdoor Learning. Available online: http://www.parliament.scot/S4_Educati onandCultureCommittee/Inquiries/SAPOE_submission.pdf (accessed on 26 September 2020).

59. Office for Standards in Education (OFSTED). An Investigation into How to Assess the Quality of Education through Curriculum Intent, Implementation and Impact. 2018. Available online: https://www.gov.uk/g overnment/publications/curriculum-research-assessing-intent-implementation-and-impact (accessed on 12 October 2020).

60. Lambert, D.; Roberts, M.; Waite, S. The National Curriculum Outdoors Series; Bloomsbury Publishers: London, UK, 2020.

Publisher's Note: MDPI stays neutral with regard to jurisdictional claims in published maps and institutional affiliations.

(C) 2020 by the author. Licensee MDPI, Basel, Switzerland. This article is an open access article distributed under the terms and conditions of the Creative Commons Attribution (CC BY) license (http://creativecommons.org/licenses/by/4.0/). 